\title{
Türk Kamu Personel Sisteminin Liyakatle İlgili Problem Sahaları Üzerine Değerlendirme (1) ${ }^{1}$
}

$\ddot{\mathbf{O} z}$

Geliş Tarihi (Received): 23.04.2021 - Kabul Tarihi (Accepted): 25.10.2021

Nitel araştırma yöntemine ait durum çalışması deseninin kullanıldığı bu çalışmada "Türk kamu personel sisteminin liyakatle ilgili problem sahaları nelerdir?" sorusuna cevap aranmıştır. Çalışmada liyakat ilkesi geniş anlamiyla "Etkin ve verimli bir personel sisteminin tesis edilmesine yönelik kural ve uygulamaların bütünü” olarak değerlendirilmiştir. Çalışmanın nesnelliğinin sağlanması için temel veri kaynakları olarak yasal düzenlemeler, resmi raporlar, yargı kararları ve Sayıştay denetleme raporları kullanılmıştır. Yasal mevzuat incelenmesi kapsamında mevcut durumun yanında tarihsel süreçteki dönüşümün de analiz edilmesi hedeflenmiştir. Yargı organları tarafından verilen kararlar üzerinden konuyla ilgili hukuki durum değerlendirilmiş, başta Sayıştay denetleme raporları olmak üzere diğer veri kaynakları kullanılarak yasal mevzuat ile uygulama arasındaki farklılıkların ortaya çıkarılmasına çalışılmıştır. Bu doğrultuda Türk kamu personel sisteminin liyakatle ilgili problem sahaları üzerine iki ayrı makale hazırlanmıştır. Bu makalede liyakatle ilgili genel konular ve liyakat ilkesinin uygulanmasına etki eden hususların yanında; hizmete alma aşamasına yönelik problemler, değerlendirme sistemi, kamu personelinin eğitimi, Devlet Memurları Kanunu ve siyaset-bürokrasi ilişkileri değerlendirilmiştir. Liyakatle ilgili diğer konular kapsamında kamuda istihdam şekillerinin liyakat ilkesi özelinde incelenmesi, görevde ilerleme ve yükselmeler, görevin sona erdirilmesi, üst kademe kamu yöneticileri, istisnai memurluk ve kariyer mesleklerle ilgili hususlar ayrı bir makalede incelenmiştir. Çalışmada alanyazında yer alan eleştirileri doğrular nitelikte bulgulara ulaşılmakla birlikte bazı konularda daha somut öneriler sunulmuştur.

Anahtar Kelimeler: Liyakat, Yeterlik, Kamu Personeli, Kamu Personel Sistemi, Kamu Yönetimi

\section{An Evaluation On The Merit-Related Problem Fields Of The Turkish Public Personnel System (1)}

\begin{abstract}
In this study, in which the case study pattern of the qualitative research method is used, and sought an answer to the "What are the problem areas of the Turkish public personnel system regarding merit?" question. In the study, the principle of merit has been evaluated as "the whole of the rules and practices for the establishment of an effective and efficient personnel system". In order to ensure the objectivity of the study, legal regulations, official reports, judicial decisions and Turkish Court of Accounts audit reports were used as the main data sources. Within the scope of the legislations, it is aimed to analyze the transformation in the historical process as well as the current situation. The legal situation regarding the topics has been evaluated based on the decisions taken by the judicial bodies. Differences between legislation and practice were tried to be revealed by using Turkish Court of Accounts audit reports and other data sources, In this direction, two separate articles were prepared on the merit related problem areas of the Turkish public personnel system. In this article, besides the general issues related to merit and the issues affecting the application of the merit principle; problems on the commissioning phase, employee appraisal system, training of public personnel, Civil Servants Law, politics-bureaucracy relations have been evaluated. Within the scope of other meritrelated issues; the examination of public servant statuses on the basis of merit principle, promotion system, termination of service, senior executives, exceptional positions and career professions have been examined in a separate article. Although the findings in the study confirm the criticisms in the literature, more concrete suggestions are presented on some issues.
\end{abstract}

Keywords: Merit, Competence, Public Personnel, Public Personnel System, Public Administration

\footnotetext{
1 Bu çalışma, Türk kamu personel sisteminde liyakat ilkesinin uygulanmasına yönelik olarak hazırlanmakta olan doktora tezinden türetilmiştir.

* Doktora Öğrencisi,Süleyman Demirel Üniversitesi, Sosyal Bilimler Enstitüsü, aguneyi@ hotmail.com, ORCID: 0000-00019984-8420
} 


\section{Giriş}

Kamuda liyakate dayalı bir yönetim uygulanması temelde iki açıdan gerekliliktir. Bunlardan birincisi Anayasa'da yer alan eşitlik ilkesinin bir gereği olarak kamu hizmetine girişte hiçbir kişi, grup veya düşünceye ayrıcalık tanınmamasının bir zorunluluk olmasıdır. Demokrasi ve hukuk devleti olmanın bir gereği olarak da kamu kadro ve pozisyonları liyakat temelinde tüm vatandaşlara açık olmalıdır. Liyakat ilkesinin uygulanmasının ikinci temel gerekçesi kamu yönetiminde başarı sağlanmasının, kamu görevlilerinin yetkinliğine bağlı olmasıdır. Gerek kamu hizmetine alım esnasında gerekse üst kademe görevlere atamalarda liyakatin esas alınması insan kaynağından en iyi şekilde faydalanmak suretiyle kamu yönetiminde etkinlik ve verimliliğin sağlanmasına en çok katkı yapacak husustur.

Bütün gelişmiş demokratik ülkelerde olduğu gibi Türkiye'de de yasal olarak liyakat ilkesi kabul edilmiştir. 1876 yılında kabul edilen Kânûn-i Esâsî’den bu yana hizmete girişte liyakat ilkesi bizzat anayasayla güvence altına alınmıştır. Kânûn-i Esâsî'nin 39'uncu maddesinde kanunlarla belirlenecek koşullara göre, kabiliyetli ve hak etmiş kişilerin memurluğa seçileceği hüküm altına alınmıştır. ${ }^{2}$ Kânûn-i Esâsî’den sonra yürürlüğe giren diğer anayasalar ve kanunlarda da liyakat ilkesi benimsenmiş, 657 sayılı Devlet Memurları Kanunu'nda (DMK) da "liyakat", "sınıflandırma" ve "kariyer" ile birlikte Türk kamu personel sisteminin üç temel ilkesinden biri olarak kabul edilmiştir.

Liyakatin kamu personel sisteminde uygulanması gereken temel ilkelerden biri olduğuna dair hiçbir tereddüt yoktur. Ancak genel olarak kabul edilen diğer bir husus Türk kamu personel sisteminde liyakat ilkesinin tam olarak hayata geçirilememiş olmasıdır. Liyakat sistemine yönelik eksiklikler gerek 1933-1963 yılları arasında yabancı uzmanlar tarafından hazırlanan raporlarda, gerek Merkezi Hükümet Teşkilâtı Araştırma Projesi (MEHTAP), Kamu Yönetimi Araştırması (KAYA) gibi resmî raporlarda, gerek kalkınma planlarında, gerekse akademisyenler tarafından yapılan çalışmalarda ${ }^{3}$ vurgulanan hususlardan biri olmuştur. 4688 sayılı Kanun kapsamında hükümet ile kamu görevlileri konfederasyon ve sendika temsilcilerinin katılımıyla yılda iki kez icra edilen Kamu Personeli Danışma Kurulu (KPDK) toplantılarında da liyakate dayalı kamu personel sistemine yönelik eksiklikler konfederasyon ve sendika temsilcileri tarafından dile getirilmektedir.

\footnotetext{
2 "Bilcümle memurin nizamen tâyin olunacak şerait üzere ehil ve müstahak oldukları memuriyetlere intihap olunacaktır..."

${ }^{3} 2020$ yılında kamu görevlilerinin liyakat algılarının incelenmesine yönelik olarak üniversitelerde görev yapan kamu görevlilerine uygulanan bir çalışmada, ankete katılan 132 kişiden sadece biri Türkiye genelinde liyakat ihlali yapılmadığını ifade etmiştir (Y1lmaz, 2020, ss. 85-111)
} 
Liyakat ilkesi kapsamında en çok tartışılan konulardan birisi siyaset ile bürokrasi arasındaki ilişkiler ve bu kapsamda siyasi iktidara kamu görevlilerinin belirlenmesine yönelik verilecek yetkinin kapsamıdır. Genel olarak kabul edilen görüşe göre liyakat ilkesinin bir gereği olarak kamu görevlilerinin siyaseten tarafsızlığının sağlanması için üst kademe kamu yöneticilerinin atanması iktidar değişikliklerinden etkilenmeyecek şekilde yapılmalıdır. $\mathrm{Bu}$ nedenle siyasi iktidarların atama yetkisi sınırsız olmamalıdır. Ancak diğer bir görüşe göre siyasi iktidarın beraber çalışacağı üst kademe kamu yöneticilerini seçme hakkına sahip olması gerekir. Bu görüşe göre siyasi otoritenin bürokrasi üzerindeki yetkisi azaldığında bürokrasi ayrı bir güç olarak siyasi otorite karşısında bir vesayet makamı hâline gelebilmektedir. Konuyla ilgili hususlar birlikte değerlendirildiğinde üst kademe kamu yöneticilerinin atanması ve görevden alınması ile ilgili temel sorunların ölçüsüzlük ve belirsizlik problemleri olduğu görülmektedir. Ölçüsüzlük problemi siyasi iktidarların üst kademe kamu yöneticilerinin atanma ve görevden alınmasına yönelik sınırsız bir yetkiye sahip olmalarıdır (Meriç, 1974, s. 78). Belirsizlik problemi ise yöneticilerin atanma ve görevden alınmalarına yönelik açık, uygulanabilir ve ölçülebilir kıstaslar belirlenmemiş olmasıdır (Albayrak, 2020a, s. 135).

Liyakatle ilgili en çok eleştirilen konulardan birisi sözlü sınav ve mülakatların bir tür kayırmacılık aracı olarak kullanılmasıdır. Yazılı sınav yerine sözlü sınav ve mülakatların tercih edilmesi sadece hizmete alma aşamasına yönelik bir eleştiri olmayıp görevde ilerleme ve yükselmelerde de sözlü sınav ve mülakat uygulaması liyakat ilkesi kapsamında eleştirilere maruz kalmaktadır. ${ }^{4}$ Liyakat ilkesi kapsamında en çok eleştirilen hususlardan bir diğeri ise istisnai memurluk kadrolarının sınavsız olarak kamu hizmetine alınma yöntemi olarak kullanılıyor olmasıdır. Liyakat ilkesine yönelik örgütlenme ihtiyacı, değişik statüdeki kamu personelinin özlük haklarına yönelik farklılıklar, görevde ilerleme ve yükselmelerle ilgili problemler, etkin bir değerlendirme sisteminin tesis edilememiş olması ve hizmet içi eğitimle ilgili eksiklikler konu kapsamında ön plana çıkan diğer önemli hususlardır.

Türk kamu personel sisteminin liyakat ilkesine yönelik problem sahalarının değerlendirileceği bu çalışmada nesnel veriler üzerinden analiz yapılarak konuyla ilgili somut bulgulara ulaşılması hedeflenmiştir. Çalışmada nitel araştırma yöntemi desenlerinden durum çalışması deseni kullanılmıştır. Durum çalışması benzersiz bir durumu ortaya koymak için

\footnotetext{
${ }^{4} 2021$ yılı Mart ayında yapılan KPDK toplantısında gündem maddelerinden birisi “Görevde Yükselme ve Unvan Değişikliği Esaslarına Dair Yönetmelik" olarak belirlenmiştir. Bu gündem kapsamında konfederasyon temsilcileri tarafindan görevde yükselme ve unvan değişikliği sınavlarında mülakat sisteminin uygulanması nedeniyle ciddi haksızlıkların yaşandığı ifade edilmiştir. Toplantıda Türkiye Kamu-Sen Konfederasyonu tarafından görevde yükselme ve unvan değişikliği sınavlarının yazılı olarak yapılmasına yönelik 657 sayılı DMK'de değişiklik öngören kanun tasarısı sunulmuştur. (https://www.kamusen.org.tr/genel-haberler/kpdk-toplantisinda-sozlesmelilere-kadro-icin-onemli-bir-adim-atildi/4656/) (Erişim:05.04.2021)
} 
yapılabileceği gibi, belli bir konuyu veya problemi en iyi şekilde anlamak için seçilmiş durum ve durumları anlamak maksadıyla da uygulanabilmektedir (Creswell, 2013, s. 98). Yin'e göre (2009, s. 18), özellikle görüngü ile bağlam arasındaki ilişkinin net olarak belli olmadığ1 durumlarda, olay doğal ortamında derinlemesine araştırılmak istendiğinde durum çalışması deseni kullanılır. Hangi uygulamaların liyakat ilkesi kapsamında daha uygun olduğunun yoruma açık olması ve liyakate dayalı kamu personel sisteminin özelliklerinin net olarak belirlenmemiş olması nedeniyle çalışmada nitel araştırma yöntemi ve durum çalışması deseni tercih edilmiştir. Çalışmada veri toplama aracı olarak doküman; verilerin analiz edilmesi maksadıyla betimsel analiz yöntemi kullanılmıştır. Verilerin çeşitlendirilmesi aynı konuda birden fazla kaynağın incelenmesi suretiyle gerçekleştirilmiştir. Bu kapsamda temel veri kaynakları; yasal mevzuat, resmi raporlar, yargı kararları ve Sayıştay raporları olmuştur. Mevzuat incelemesi neticesinde mevcut yasal durumun yanında mevzuatta yapılan değişiklikler üzerinden konuyla ilgili dönüşümün de ortaya çıkarılmasına çalışılmıştır. Yargı organları tarafindan verilen kararlar üzerinden konuyla ilgili hukuki durum değerlendirilmiştir. Sayıştay denetleme raporları ile diğer resmi raporlarda yer alan tespitler incelenmek suretiyle yasal mevzuat ile uygulama arasındaki farklar analiz edilmiştir.

\section{Liyakat İlkesi ve İlkenin Uygulanmasına Etki Eden Hususlar}

Arapça kökenli olup batı dillerinde "merit" terimine karşılık gelen "liyakat" kelimesi Türk Dil Kurumu sözlüğünde “Bir kimsenin, kendisine iş verilmeye uygunluk, yaraşırlık durumu, değim" ve "kifayet" olarak açıklanmaktadır. Liyakatin eş anlamlıs1 "yeterlik"tir. Literatürde liyakatle ilgili konular tartış1lırken bazen "liyakat ilkesi" bazen de "liyakat sistemi" ifadeleri kullanılmaktadır. Liyakat, kamu personel sisteminde uygulanması gereken esaslardan biri olarak nitelendirildiğinde "ilke"; liyakati esas alan uygulamalar bütünü olarak değerlendirildiğinde ise "sistem" olarak adlandırılabilir.

Kamu personel sistemi açısından liyakat ilkesi dar anlamda "Kamu görevleri için en yetenekli elemanların seçilmesi" olarak açıklanmaktadır. Geniş anlamda ise liyakat "Kamu görevlerine girişin ve hizmet içinde yükselişin karşılaştırma temeline dayalı 'işe uygunluk' ya da 'başarı' ölçütüne bağlandiğı ve uygulanan ücret ve öteki çalışma koşullarının hizmetin etkinliği ve sürekliliğine katkıda bulunduğu bir personel sistemi" olarak ifade edilmektedir (Tutum, 1979: ss. 18-20). Görüldüğü üzere geniş anlamda değerlendirildiğinde liyakat ilkesi

etkin ve verimli bir personel sisteminin tesis edilmesi için gerekli olan kural ve uygulamalar bütünü olup (Aykaç, 1990, s. 99; Canman, 1995, s. 17; Tutum, 1979, s. 19) bu çalışmada da ilke geniş anlamıyla değerlendirilmiştir. 
Alanyazında liyakatle ilgili çalışmalar incelendiğinde liyakat sisteminin ilkelerinin genel itibariyle ABD sisteminin ilkeleri üzerinden açıklandığı görülmektedir (Akgüner, 2014, ss. 34-35; Güran, 1980, ss. 135-155). ABD Kanunu'nun (The United States Code) 5 “Hükümet Yapısı ve Çalışanlar (Goverment Organization And Employees)" başlıklı beşinci bölümünün 2301 sayılı maddesinde liyakat sistemine yönelik uygulanacak dokuz adet ilke belirlenmiştir. ABD Liyakat Sistemini Koruma Kurulu (U.S. Merit Systems Protection Board-MSPB) ${ }^{6}$ tarafından da bu ilkeler esas alınmaktadır. Birinci ilke kapsamında kamu hizmetine girişte tüm kesimlerin temsili sağlanmalı; hizmete alma, ilerleme ve yükselmelerde tek ölçüt personelin bilgisi, becerisi ve yeteneği olmalıdır. Personelin yeterliliği herkesin eşit koşullar ve imkânlar altında yarıştığı açık ve adaletli bir şekilde düzenlenmiş objektif yarışmalarla ölçülmelidir. İkinci ilke kapsamında kamu personel sisteminin her aşamasında tüm adaylar ve kamu çalışanlarına siyasi bağlantısı, ırkı, rengi, dini, milliyeti, cinsiyeti, medeni durumu, yaşı, bedensel özür durumu gibi özelliklerine bakılmaksızın eşit ve adaletli davranılmalı, özel hayatın gizliliği ve anayasal haklara saygı gösterilmelidir. "Eşit işe eşit ücret" olarak da tanımlanan üçüncü ilke kapsamında özel sektör tarafından verilen ücretler de dikkate alınarak kamu personeline yönelik yeterli, adaletli ve başarılı personeli teşvik eden bir ücret sistemi uygulanmalıdır. Dördüncü ilke kapsamında tüm kamu çalışanları kamu yararı bilincine ve bu niteliğin gerektirdiği özelliklere sahip olmalıdır. Beşinci ilke kapsamında kamu işgücü etkin ve verimli bir şekilde kullanılmalıdır. Altıncı ilke yetersiz personelin görevinin sonlandırılması ile ilgilidir. Bu ilke kapsamında performansı yetersiz olan kamu personelinin eksikliklerini tamamlaması için imkân tanınmalı, buna rağmen yeterli standartlara ulaşamayan personelin görevine son verilmelidir. Yedinci ilke kapsamında örgütsel ve bireysel performansın artırılması için kamu personeline etkin bir eğitim ve öğrenim sağlanmalıdır. Sekiz ve dokuzuncu ilkeler kamu personeline sağlanan güvencelere yöneliktir. Sekizinci ilke kapsamında kamu çalışanları keyfi eylem, kişisel kayırmacılık veya siyasi amaçlarla partizan zorlamalara karşı korunmalıdır. Bununla beraber kamu görevlilerinin resmi yetki ve etkilerini herhangi bir kişinin adaylığına ya da siyasal seçim sonuçlarına müdahale etmek veya etkilemek maksadıyla kullanması yasaklanmalıdır. Dokuzuncu ilke kapsamında kamu personeli herhangi bir yasa, kural veya yönetmeliğin ihlali; kötü yönetim, kamu kaynağının israf edilmesi, yetkinin kötüye kullanılması, halk sağlığı ve güvenliğini tehlikeye atabilecek önemli bir durumun ortaya

\footnotetext{
${ }^{5}$ https://uscode.house.gov/browse.xhtml (Erişim:05.04.2021)

${ }^{6} \mathrm{https}: / /$ www.mspb.gov/index.htm (Erişim:05.04.2021)
} 
çıkması hâlinde hukuka uygun bir şekilde kanıt olarak kullanılabilecek bilgilerin ortaya çıkarılması sonrasında maruz kalabilecekleri misillemelere karşı korunmalıdırlar.

Türk kamu personel sistemine ait yasal mevzuatta liyakat sisteminin esasları ABD'deki gibi ayrıntılı olarak ifade edilmemiştir. Anayasa'nın 70'inci maddesinde her Türk vatandaşının kamu hizmetlerine girme hakkına sahip olduğu; hizmete alınmada, görevin gerektirdiği niteliklerden başka hiçbir ayrımın gözetilemeyeceği ifade edilerek hizmete alma aşaması kapsamında liyakat ilkesi anayasal olarak güvence altına alınmıştır. 657 sayılı DMK'de ise liyakat "Devlet kamu hizmetleri görevlerine girmeyi, slnıflar içinde ilerleme ve yükselmeyi, görevin sona erdirilmesini liyakat sistemine dayandırmak ve bu sistemin eşit imkânlarla uygulanmasında Devlet memurlarını güvenliğe sahip kılmak” olarak tanımlanmıştır. Görüldüğü üzere Kanun'da hizmete alma, görevde ilerleme ve yükselmeler ve görevin sona erdirilmesi aşamalarında liyakatin esas alınacağı belirtilmekle beraber liyakat sisteminin alt unsurları tanımlanmamıştır. Kamu personelinin tarafsızlığı, personele sağlanan güvenceler, ücret adaleti, kamu personelinin eğitimi gibi liyakatle ilgili diğer konular tanıma dâhil edilmemiştir. Bununla beraber her ne kadar liyakat ilkesi ile bağlantısı kurulmamış olsa da kamu personelinin tarafsızlığının sağlanması kapsamında söz konusu personel idare ve üçüncü kişilere karşı yasal olarak güvencelere sahip kılınmıştır. Anayasa'nın 129'uncu maddesi kapsamında memurlar ve diğer kamu görevlileri idarenin eylemlerine ve üçüncü kişilerin haksız isnatlarına karşı bir takım güvencelere haiz kılınmış, ayrıca bu konularda yasal düzenlemeler de yapılmıştır.

Gelinen noktada ABD'de olduğu gibi Türk kamu personel sisteminde de liyakate dayalı personel sisteminin uygulanabilmesi için gerekli esasların daha açık olarak belirlenmesinin ve uygulamasının takip edilmesinin bir gereklilik olduğu söylenebilir. Ancak bu doğrultuda belirlenecek esasların herhangi bir ülke uygulamalarından uyarlanmak yerine kendi örgüt yapımıza uygun olması gerekmektedir. Örneğin ABD'de kabul edilen "eşit işe eşit ücret" ilkesinin Türkiye'de uygulanabilirliği tartışmalıdır. Güler'e göre söz konusu ilke ABD gibi iş (kadro) sınıflandırma sisteminin uygulandığı ülkelerde geçerlidir. Bu sistemde sınıflar ve bu sınıflara (kadrolara) ait nitelikler ayrıntılı olarak belirlenmiş olup bir kadroya bağlı olarak yapılan memurluk ömür boyu sürdürülecek bir meslek değildir. Oysa Türkiye'de kariyer (rütbe) sınıflandırma sistemi uygulanmakta olup kadro kaldırılsa dahi memurun kamudaki görevi devam etmektedir. Memura yapılan ödeme kişinin performansına göre değil mevkisine göre yapılmaktadır. Kariyer sınıflandırma sisteminde "Eşit işe eşit ücret" ilkesi geçerli olmayıp memurlara ödenecek maaş kişinin saygınlığı ve devleti temsil etme gücüyle toplumsal geçim arasında kurulan denge esas alınarak belirlenmektedir (Güler, 2013, ss. 194-197; 241). Türk 
kamu personel sisteminde kamu kurum ve kuruluşlarında benzer görevleri yapan personelin farklı ücretler almasından kaynaklanan adaletsizlik problemi de zaman zaman "eşit işe eşit ücret" ilkesinin ihlali olarak ifade edilmektedir. Ancak Güler'e göre (2013, s. 315) bu sorun "eşit işe eşit ücret" değil "tevhid ve teadül", yani "birlik ve denklik" sağlama problemidir.

ABD ile Türk kamu personel sistemi arasındaki diğer bir farklılık kariyer ile liyakat ilkeleri arasındaki ilişkidir. İş sınıflandırma sisteminin esas alındığı ABD’de Türk kamu personel sisteminde kabul edilen kariyer ilkesi geçerli değildir. Oysa Türk kamu personel sistemi açısından değerlendirildiğinde birçok akademisyene göre kariyer sistemi liyakat sisteminin bir ön koşulu olup her iki sistem birlikte uygulanmalıdır (Aykaç, 1990, s. 99; Gönülaçar, 2014, s. 7; Güran, 1980, s. 130; Sezer, 2003, s. 180; Şen, 1995, s. 81).

\subsection{Liyakate Karşı Kayırmacılık}

Kamu personel sistemi açısından incelendiğinde kayırmacılığı iki ayrı şekilde değerlendirmek gerekir. Bunlardan birincisi kamu hizmetine girişte liyakatin ikinci planda bırakılarak, bunun yerine; akraba, tanıdık, arkadaş, hemşehri veya siyasi yakınlık gibi faktörlerin ön plana çıkarılmasıdır. Bu anlamda kamu personel sistemi açısından kayırmacılık uygulamaları genel itibariyle; akraba kayırmacılığı (nepotizm), eş-dost kayırmacılığı (kronizm) ve siyasi kayırmacılık olarak sıralanabilir. Liyakat bir sistem olarak değerlendirildiğinde ise karşıt1, bir dönem ABD'de resmi olarak kabul edilen "spoils system" veya "patronage system" olarak adlandırılan "kayırmacılık sistemi”dir. Bu açıdan değerlendirildiğinde kamu personel rejimlerinde uygulanacak iki sistemden biri "liyakat sistemi (merit system)" iken diğeri “kayırmacılık sistemi”dir. İki sistem arasındaki temel fark siyasi otoriteye kamu örgüt yapısının ve kamu personelinin belirlenmesine yönelik olarak verilen yetkiden kaynaklanmaktadır.

Kayırmacılık sisteminin temel kabulü, seçimle işbaşına gelen ve seçmene karşı sorumlu olan siyasi iradenin, seçimle birlikte devlet kadrolarına kendi ideolojisine ait kişileri yerleştirme hakkını da kazanmış olduğu düşüncesi olmuştur. Bu görüşe göre özellikle üst kademe yöneticilik görevleri siyasi iktidarın görev süresi ile sınırlandırılmalı ve siyasi iktidar istediği zaman bu kişileri görevden alabilmelidir (Eryılmaz, 2016, s. 381). Kayırmacılık sisteminin diğer bir kabulü ise "memurluğun" tüm vatandaşlar tarafından yapılabilecek basitlikte olduğudur. Kayırmacılık sistemine göre memurluk uzun süre meslek olarak yapıldığında mülkiyet olarak algılanmakta ve özel çıkarların ön planda olduğu kapalı, halktan kopuk bir sistem hâline gelmektedir. Bu durumda kayırmacılık sistemi kapalı kariyer sistemini tamamen reddetmiştir. Liyakat sisteminde ise kamu hizmetlerinin objektif esaslara göre toplumun tüm kesiminden seçilen kişiler tarafından yerine getirilmesi esastır. Liyakat sisteminde kamu 
görevlilerinin siyaseten tarafsızlığının sağlanması özel önem arz etmekte olup bu kapsamda kamu görevlilerinin idare ve üçüncü kişilere karşı korunması için gerekli güvencelerin sağlanmas1 gerekir.

ABD'de 1789-1883 yılları arasında resmî olarak yürürlükte olan kayırmacıllık sistemi, uygulamanın kamu hizmetlerinin sürekliliği ilkesiyle bağdaşmaması, yapılan atamaların görevin gerekleriyle uyuşmaması, rüşvet, komisyonculuk, görevi kötüye kullanma gibi olumsuzlukların artması ve hazinenin zarara uğratılması gibi olumsuzluklar neticesinde toplumsal bir sorun hâline gelmiştir. Bunun neticesinde 1883 yılında George H. PENDLETON tarafından önerilen Pendtleton İlkeleri esas alınarak liyakat sistemine geçilmiştir (Aykaç, 1990, s. 101; Güran, 1980, ss. 94-95). Liyakat sistemine geçişi müteakip Amerikan kamu idaresini niteleyen "partizanca temsiliyet" ilkesi yerini, toplumun tüm kesimlerinin kamu görevlerine alınmasını öngören "toplumsal temsiliyet" ilkesine bırakmıştır (Dreyfus, 2007, s. 285). Günümüzde ABD ile birlikte tüm gelişmiş ülkelerde liyakat sistemi benimsenmiştir. Ancak sistemin uygulamada ne kadar hayata geçirildiği tartışmaya açık bir husustur.

\subsection{Türk Kamu Personel Sisteminde Liyakat İlkesinin Uygulanmasına Etki Eden}

\section{Hususlar}

Liyakat ilkesine yönelik problem sahalarına ayrıntılı olarak girmeden önce bu problemlere temel teşkil eden üç hususu vurgulamak gerekir. Bunlardan ilki toplumun sosyokültürel özelliklerinin liyakat ilkesinin uygulanmasına etkisidir. Türk toplumunda vatandaşlar gerek resmî, gerekse özel işlerinin görülmesi esnasında tanıdık ve aracılar kullanmak eğilimindedirler. Aracılar vasıtasıyla iş görme eğiliminin en çok olduğu alanlardan biri de kamuda işe girebilmektir. Bu durum sadece Türkiye'ye özgü olmamakla birlikte Türk toplumunda oldukça yaygın olduğunu ifade etmek gerekir. Kayırmacılık uygulamalarına zemin oluşturan bu toplumsal yapı liyakat ilkesinin tam olarak hayata geçirilmesi karşısındaki en önemli engellerden biridir.

Liyakat ilkesinin tam olarak uygulanmasını zorlaştıran ikinci unsur kamu örgüt yapısından kaynaklanan sıkıntılardır. Hiyerarşik yapılanma, yasal mevzuata sıkı sıkıya bağlılık, iç ve dış denetim mekanizmaları gibi unsurların bir araya gelmesi neticesinde oluşan bürokratik yapı kamu örgüt yapısının "şekilcilik”, “hantallık” gibi olumsuz özelliklere sahip olmasına neden olabilmektedir. Bunun yanında kamu personelinin işe girerken gösterdikleri istek ve çabayı işe girdikten sonra da devam ettirdiği söylenemez. Bu durumda kamu personelinin "duyarsıllk", "nemelazımcılık" gibi nitelikleri de kamu personel sisteminde liyakat ilkesinin uygulanmasını zorlaştırmaktadır. Yabancı uzmanlar tarafından hazırlanan raporların 
birçoğunda (Dorr Raporu, Neumark Raporu, Barker Raporu, Martin ve Cush Raporu) verimsiz ve liyakatsiz memurlara vurgu yapılmış, bu tür personelin yasal mevzuatla korunduğu, çalışmayan memurların da görevde kalmaya devam ettiği ifade edilerek ehliyetsiz personelin işten çıkarılmasına yönelik uygulamaların eksikliği dile getirilmiştir. Üçüncü Beş Yıllık Kalkınma Planı’nda (1973-1977) kamu kesiminin işleyişindeki en önemli sorunlardan birisinin “duyarsızlık" olduğu belirtilerek birçok kurumda işlerin üstün görev duygusuna sahip az sayıdaki personelin çabası sayesinde yürüdüğü ifade edilmiştir. 1991 yılında yayımlanan KAYA Raporu'nun “Halkla İlişkiler ve Enformasyon” bölümünde, insan ilişkilerindeki duyarsızlık kamu yönetiminde görülen sorunlardan birisi olarak ifade edilmiş, kurumsal geleneklere aşırı bağımlılık ve örgütsel değişmeye direnme duyarsılı̆ı̆ıı nedenleri arasında sayılmıştır.

Liyakat ilkesi ile ilgili üçüncü temel problem sahası, üzerinde en çok tartışılan siyaset bürokrasi ilişkileri üzerinedir. Daha önceden de ifade edildiği üzere kayırmacılık sisteminde seçimleri kazanan iktidarın beraberinde devlette kadrolaşma hakkını da kazandı ̆̆ı kabul edilmekte iken, liyakat sisteminde kamu personelinin siyasi tarafsızlığı önem arz etmektedir. Türkiye'de de resmî olarak liyakat ilkesi kabul edilmekle birlikte siyasetçiler Güran'ın ifadesi ile "yanlı memurların egemenliğindeki yanlı İdare Cihazını" oluşturma tutkularından vazgeçmemişlerdir. Güran, 1980 yılında yayımlanan çalışmasında Türkiye'de ne "kayırma”, ne "liyakat" ne de iki sistemin rasyonel bir karmasının uygulanmakta olduğunu, uygulamadaki sistemin sistemsizlik olduğunu ifade etmiştir. Güran'a göre Anayasa'da ve yasalarda liyakat sistemi kabul edilmiş olduğundan kayırmacılık " $b u$ adla ve açıkça” uygulanma imkânı bulamamakta, ancak yönetime esneklik ve dinamizm getirmek gibi gerekçelerle memurların derecelerin yükseltilmesi veya yer değiştirmeleri gibi konularda yapılan yasal düzenlemelerle kamu yararı gereği yerine getiriliyormuş gibi gösterilmek suretiyle açıkça partizanlık ve kayırmacılık uygulanmaktadır (Güran, 1980, ss. 315-318).

1980 yılından sonraki dönemde de siyasetçilerin bürokrasi üzerinde hâkimiyet kurma isteklerinden vazgeçmediğini söylemek yanlış olmayacaktır. Nitekim Cumhurbaşkanlığı Hükümet Sistemine geçiş kapsamında 2017 yılında anayasa değişikliği ile yapılan düzenlemelerle yürütme erkinin başı konumunda olan Cumhurbaşkanına üst kademe kamu yöneticilerini atama ve görevlerine son verme ile birlikte bu personelin atanmalarına ilişkin usul ve esasları Cumhurbaşkanlığı Kararnamesiyle düzenleme yetkisi de verilmiştir. 3 sayılı Cumhurbaşkanlığı Kararnamesiyle yapılan düzenleme kapsamında üst kademe kamu yöneticilerinin görev süresinin Cumhurbaşkanının görev süresi ile sınırlandırılması ile birlikte 
kayırmacılık sisteminde tatbik edilen yürütme organı ile birlikte kamu personelinin de değiştirilmesi uygulaması ilk kez yasal zemin bulmuştur.

Siyasi iktidarların bürokrasi üzerinde hâkimiyet kurma isteklerinin dayanağ1 bürokrasinin ayrı bir güç olması durumunda iktidarın politikalarına ayak diremesi olmuştur. $\mathrm{Bu}$ kapsamda en çok tartışılan dönem 1950 yılı itibariyle Demokrat Partinin iktidara gelmesiyle başlayan yıllardır. Tek parti dönemindeki Cumhuriyet Halk Partisi ile bürokrasi arasındaki bütünlük Demokrat Partinin iktidara gelmesiyle birlikte bozulmuş, demokrasi ve devrimlerin korunması görevinin kendilerine düştügüne inanan sivil bürokrasi Demokrat Partiyi Cumhuriyet değerlerine karşı bir tehdit olarak görmüştür. $\mathrm{Bu}$ dönemde iktidar partisinin bürokrasinin siyasal gücünü kırma çabaları, etkin ve verimli bir bürokratik yapı oluşturma çabalarının önüne geçmiştir (Heper, 1977, s. 100). 27 Mayıs 1960 tarihinde gerçekleşen askerî darbe sonrası askerî bürokrasi ön plana çıkmaya başlamış, sivil bürokrasinin etkinliği azalmıştır. 27 Nisan 2007 tarihinde Genelkurmay Başkanlığg resmî internet sitesinde yayımlanan ve "E-Muhtıra" olarak da nitelendirilen basın bildirisi askerî bürokrasinin siyasi iktidara yönelik son müdahalesi olmuştur. Bu dönemden sonra askerî bürokrasinin de siyaset üzerindeki etkisi azalmaya başlamıştır.

15 Temmuz 2016 tarihinde gerçekleşen başarısız darbe teşebbüsü sonrası çıkarılan Kanun Hükmünde Kararnameler (KHK) ve kanunlar ile Cumhurbaşkanlığı Hükümet Sistemine geçiş sonrası yapılan diğer düzenlemelerle askerî bürokrasinin de siyaset karşısında ayrı bir güç olma özelliği kalmamıştır. Yapılan düzenlemelerle Millî Güvenlik Kurulu ve Yüksek Askerî Şûra'da (YAŞ) asker üyelerin sayısı ve etkinliği azaltılmıştır. Genelkurmay Başkanlığı ve kuvvet komutanlıklarının ayrı ayrı Millî Savunma Bakanlığına bağlanması, mevcut rütbesinde bir sene görev yapmış albay, general ve amirallerin YAŞ kararıyla bir üst rütbeye yükseltilmesi veya emekli edilebilmesi gibi TSK teşkilatı ve personel işlemlerine yönelik yapılan diğer düzenlemelerle Silahlı Kuvvetler sivil otoriteye daha bağımlı hâle getirilmiş, albay/general/amirallerin terfi ettirilmesi veya emekliye sevk edilmesine yönelik siyasi otoriteye esneklik sağlanmıştır. Dolayısıyla mevcut durum itibariyle gerek sivil, gerekse askerî bürokrasinin hükümet politikalarına karşı koyma yönünde bir etkisinin olmadığı söylenebilir.

Siyaset-bürokrasi ilişkileri kapsamında tartışılan diğer bir husus kamu görevlilerine sağlanan güvencelerin bürokrasiyi ayrı bir güç hâline getirmesinin yanında kamuda hantallık ve verimsizliğe yol açmasıdır. Kamu örgüt yapısının liyakat ilkesinin uygulanmasına etkisinin değerlendirildiği bölümde de ifade edildiği üzere bu eleştirilerin haklılık payı vardır. Kamu görevlilerine sağlanan mesleki güvenceler, etkin bir değerlendirme sisteminin de tesis 
edilememiş olması ile birleşince kamuda verimsizliğe neden olabilmektedir. Kamuda güvenceli istihdamdan esnek istihdama yönelmenin gerekçelerinden birisinin de bu olduğu söylenebilir. Diğer yandan kamu hizmetlerinin görülmesinde tarafsızlığının kamu görevlilerinin siyaset, idare ve üçüncü kişilere karşı korunması ile sağlanabileceği (Güler, 2013, s. 153) göz önüne alındığında bir açmaz ortaya çıkmaktadır. Kamu görevlilerinin siyasetin ve çıkar gruplarının etkisinden korunması ve üçüncü kişilerin haksız suçlamaları nedeniyle mağduriyet yaşamamaları için bu personele sağlanan güvencelerin korunması gerekir. Diğer yandan etkin bir değerlendirme sistemi tesis edilerek yetersiz personele yönelik, memuriyetten çıkarılmak da dâhil olmak üzere gerekli yaptırımların uygulanması da kamu yönetiminde etkinlik ve verimliliğin sağlanması için bir gereklilik olup aynı zamanda liyakat ilkesinin bir gereğidir.

Netice olarak siyaset ile bürokrasi arasındaki ilişkiler liyakat ilkesi kapsamında bütüncül olarak değerlendirildiğinde siyasetçilerin bürokrasiye etkisinin daha çok ön plana çıktığ görülmektedir. Bu noktada Sekizinci Beş Yıılık Kalkınma Planı (2001-2005) hazırlıkları kapsamında hazırlanan özel ihtisas komisyonu raporlarından birisi olan "Kamu Yönetiminin Iyileştirilmesi ve Yeniden Yapılandırılması Özel İhtisas Komisyonu Raporu”nda "Siyasilerin Kamu Personeli Üzerindeki Etkilerinin Azaltılması" isimli ayrı bir bölüm hazırlanması dikkat çekicidir. Rapor'da her hükümet değiş̧ikliğinde bürokraside de değişiklikler olduğu ifade edilerek; kamu personelinin seçimi, ataması ve görevde yükselmesi süreçlerinde politikacıların etkili olmasının hizmetlerin sürekliliği ve verimliliğini olumsuz olarak etkilediği, aynı zamanda kamu personeli üzerinde de olumsuz etki yaptı̆̆g belirtilmiştir.

Görüldüğü üzere toplumun sosyokültürel özellikleri, kamu örgüt yapısından kaynaklanan problemler ve siyasetin kamu yönetimi üzerinde mutlak hâkimiyet kurma isteği kamuda liyakate dayalı bir personel sistemi tesis edilmesini zorlaştıran unsurlardır. $\mathrm{Bu}$ kapsamda bu zafiyetlerin giderilmesi için kamu personel sisteminin her aşamasına yönelik liyakati esas alan genel ve standart düzenlemeler yapılması ihtiyacı ön plana çıkmaktadır. Ancak bu noktada yapılan yasal düzenlemelerin liyakate dayalı kamu personel sisteminin tesisi için yetersiz kaldığını ifade etmek gerekir. Yasal düzenlemelerin yetersizliği başlıca iki şekilde ortaya çıkmaktadır. Bunlardan birincisi mevcut yasaların esnetilmesi veya istisnalar getirilmesi suretiyle kayırmacılık uygulamalarına alan açmak şeklinde ortaya çıkmaktadır. İstisnai memurluk kadrolarının devamlı olarak artması, üst kademe kamu yöneticiliğine atanmak için belirlenen nesnel ölçütlerin kaldırılması, merkezi sınav sonuçlarına göre yerleşilen memuriyet kadrolarının azaltılması bu tür düzenlemelere örnek olarak gösterilebilir. Bir kısım kayırmacılık uygulamaları ise yasal düzenlemelerdeki boşluklardan faydalanmak suretiyle veya bizzat 
yasalara aykırı olarak yapılmaktadır. Sözlü sınavların ve mülakatların kayırmacılık ve eleme aracı olarak kullanılması, istisnai memurluk kadrolarının sınavsız olarak memuriyete geçiş amacıyla kullanılması, üst kademe yöneticilik kadrolarının sınava tabi olan müdür, şef gibi kadrolara sınavsız olarak atanma amacıyla kullanılması, vekâleten atamaların genel ve sürekli bir uygulama hâline dönüşmesi, üniversite öğretim üyeliklerine adres göstererek alım yapılması bu tür uygulamalara örnektir.

Yasal düzenlemelerin yetersiz kalması ve zamanla kayırmacılık uygulamalarına neden olabilecek şekilde esnetilmesi, liyakate dayalı bir kamu personel sistemi tesis edilmesine yönelik ikinci bir ihtiyacı ortaya çıkarmaktadır. Bu da belirli ilkeler doğrultusunda liyakati esas alan bir sistemin tesis edilmesi için gerekli düzenlemeleri süreklilik arz edecek şekilde yapacak, sistemi değerlendirecek, şikâyetleri inceleyecek, problem sahalarını tespit edip düzeltici tedbirleri alacak merkezi bir örgütün kurulması ihtiyacıdır. İlerleyen bölümde Türk kamu personel sisteminin liyakate yönelik problem sahalarının değerlendirilmesini müteakip sonuç kısmında merkezi örgütlenme ihtiyacı tekrar tartışılacaktır.

\section{Liyakat İlkesinin Uygulanmasına Yönelik Problem Sahaları}

Kamu personelinin görevini layıkıyla yerine getirebilmesi için görevin gerektirdiği eğitimlerin kendisine verilmesi, aynı zamanda üst kademe görevlere de hazırlanması gereklidir. Hizmete alma esnasında kişinin görev için yeterliliğinin tam olarak ölçülemiyor olması hizmet içi eğitimin önemini daha da artırmakta, aynı zamanda adaylık müessesesini gerekli kılmaktadır. Bunun yanında hak eden kişilerin üst kademe görevlere yükseltilmesi, yapılan uyarılara rağmen görevinde başarılı olamayan kamu personelinin ise görevine son verilmesi liyakat ilkesinin bir gereğidir. Bunun için de etkin ve adaletli bir değerlendirme sisteminin tesis edilmesi bir zorunluluktur. Çalışmanın bu bölümünde liyakatle ilgili hususlar kapsamında hizmete alma aşamasına yönelik problemler, değerlendirme sistemi, hizmet içi eğitim ve 657 sayılı DMK değerlendirilecektir.

\subsection{Hizmete Alma Așamasına Yönelik Problem Sahaları}

1965 yılında yürürlüğe giren 657 sayılı DMK'nin ilk hâlinde şu anda uygulanan (A) grubu ve (B) grubu kadro ayrımına benzer șekilde "kurumlar arası sınıf" ve "kurumsal sınıf" ayrımı öngörülmüştür. Kanun'da “kurumlar arası sınıf” kadrolarına alınacak personelin yarışma sınavlarının Devlet Personel Dairesi tarafından; "kurumsal sınıflara" alınacak personelin yarışma sınavlarının ise Devlet Personel Dairesinin gözetimi altında ilgili kurum tarafından yapılması usulü benimsenmiştir. 657 sayılı DMK ile öngörülen sistem uygulamaya 
geçirilememiş, 1970 yılında 1327 sayılı Kanun ile yapılan düzenleme ile "kurumlar arası sınıf kavramı" iptal edilerek merkezi sınav uygulamasından vazgeçilmiştir. 12 Mayıs 1982 tarihinde kabul edilen 2670 sayılı Kanun'la merkezi sınav sistemi ilkesine geri dönülmüş, ancak 29 Kasım 1984 tarihinde onaylanan 243 sayılı KHK ile merkezi sınav sisteminden vazgeçilerek tekrar kurumsal sınav sistemi benimsenmiştir. Bakanlar Kurulunun 02 Şubat 1999 tarihli ve 99/12377 sayılı kararı ile hizmete almada merkezi sisteme geçişin ilk adımının atılmasını müteakip, devlet memurluğuna giriş için merkezi sınav ilk olarak 17 Ekim 1999 tarihinde uygulanabilmiştir.

Merkezi sınav sistemine geçilmesinin hizmete alma aşamasında kayırmacılığın engellenmesi açısından yapılan en önemli düzenleme olduğu söylenebilir. Nitekim bu ihtiyaç kamu yönetimine yönelik olarak hazırlanan birçok raporda dile getirilmiştir. 1963 yılında MEHTAP Raporu'nda (s. 77, 80) personelin hizmete alınması konusunda merkeziyetçilik lehinde kuvvetli deliller olduğu ifade edilerek, kısmen de olsa merkezi personel tedariki yönünde adım atılması önerilmiştir. 1971 yılında hazırlanan İdari Reform Danışma Kurulu Raporu'nda (s. 165) merkezi sınav sisteminin liyakat ilkesi kapsamında önemi vurgulanarak, hizmete almanın kurumların takdirine bırakılması ve gelişigüzel işletilmesi liyakat ilkesi kapsamında eleştirilen hususlardan biri olmuştur. 1991 yılında KAYA Raporu'nda (s. 200) ise belirli ortak görev unvanlı, kurumlar arası kadrolara açıktan personel alımında merkezi sınav sisteminin uygulanması gerektiği belirtilmiştir.

Görüldüğü üzere 1960'lardan itibaren dile getirilen merkezi sınav sistemine geçilme ihtiyacı ancak 1999 yılında uygulamaya konulabilmiştir. Bununla beraber merkezi sınav sisteminin kamuda liyakat temelli işe alınma sürecinin gerçekleştirilmesi için tek başına yeterli olmadığının belirtilmesi gerekir. Öncelikle her ne kadar 657 sayılı DMK'nin 50'nci maddesinde "Devlet kamu hizmet ve görevlerine Devlet memuru olarak atanacakların açılacak Devlet memurluğu sınavlarına girmeleri ve sınavı kazanmalarının” şart olduğu ifade edilmiş olsa da, sınav şartı tüm hizmete alımlarda geçerli değildir. 657 sayılı DMK'nin 224 ve 225'inci maddelerinde belirtilen esaslar doğrultusunda mecburi hizmetle yükümlü bulunanlar yarışma sınavına tabi tutulmaksızın atanmaktadırlar. 3713 sayılı Terörle Mücadele Kanunu kapsamında harp ve vazife malulü sayılanlar ile şehit yakınları; 4857 sayılı İş Kanunu'nun otuzuncu maddesi kapsamında, eski hükümlüler ve terörle mücadelede malul sayılmayacak şekilde yaralananlar sınavsız olarak kamuda istihdam edilebilmektedir. 3269 sayılı Uzman Erbaş Kanunu'na göre, yaş sınırı nedeniyle Silahlı Kuvvetlerden ayrılan uzman erbaşlardan istekli olanlar emekli aylığına hak kazandıkları tarihe kadar devlet memuru olarak görev 
yapabilmektedirler. Uzman tabip, tabip, diş tabibi gibi bazı sağlık personelinin açıktan atamaları kura yoluyla yapılmaktadır. Sosyal devlet olma ilkesinin bir gereği olarak özürlüler ve Sosyal Hizmetler ve Çocuk Esirgeme Kurumu Genel Müdürlüğ̈ tarafindan yetiştirilen korunmaya muhtaç çocuklar kendi aralarında sınava tabi tutularak belli kontenjanlar doğrultusunda kamu kurum ve kuruluşlarına yerleştirilmektedir.

Bir ihtiyaca veya özel duruma istinaden yapılan bu tür düzenlemeleri liyakat ilkesine aykırı uygulamalar olarak nitelemek mümkün değildir. Ancak bunların dışında olup liyakat ilkesi açısından problemli sayılabilecek sınavsız kamu hizmetine alma yöntemleri de uygulanmaktadır. Bunlardan birisi liyakat ilkesi kapsamında en tartışmalı konulardan biri olan istisnai memurluklardır. Açıktan üst kademe kamu yöneticisi atamalarını da sınavsız kamuda istihdam yöntemi olarak değerlendirmek mümkündür.

Liyakat ilkesi kapsamında problemli diğer bir sınavsız hizmete alma yöntemi vekâleten hizmete alma uygulamasıdır. 657 sayılı DMK'nin 86'nc1 maddesinde “Memurların kanuni izin, geçici görev, disiplin cezası uygulaması veya görevden uzaklaştırma nedenleriyle işlerinden geçici olarak ayrılmaları halinde" yerlerine vekil atanabileceği belirtilmiştir. Vekâleten yapılacak atamalar kurum içinden veya diğer kurumlardan olabileceği gibi açıktan vekil atanması da mümkündür. Bununla beraber açıktan, sınavsız olarak, vekâleten kamu hizmetine alınanlar daha sonra kadroya geçirilebilmektedir. Örneğin 27 Nisan 2005 tarihinde kabul edilen 5338 sayılı Kanun ile askerlik hizmeti nedeniyle görevden ayrılmış olanlar da dâhil olmak üzere imam-hatip kadrolarında vekâleten görev yapmakta olan on bine yakın vekil imam yarışma sınavına girmeksizin kadroya geçirilmiştir. 5338 sayılı Kanun'da atanma şartı, KPSS sınavlarının herhangi birinden Diyanet İşleri Başkanlığınca belirlenecek yeterli puanı almış olmak olarak belirlenmiştir. Bu durumda KPSS sınavından 90 ve üzeri alan personel dâhi kamuda işe giremeyebilmekte iken çok daha düşük not alan bir kişi kamuda istihdam edilebilmektedir.

Vekâleten açıktan atamalarla birlikte vekâleten görevlendirmeler de liyakat ilkesi kapsamında tartışmalıdır. 657 sayılı DMK'nin 86'ncı maddesinde vekâleten atamalar geçici bir uygulama olarak öngörülmüştür. Ancak Sayıştay raporları incelendiğinde vekâleten atamaların genel bir uygulama hâline dönüştüğü ve kanunlarda belirtilen şartları sağlamayan kişilerin vekil olarak atandığı görülmektedir. 2019 Yılı Gelir İdaresi Başkanlığı Sayıştay Denetim Raporu'nda (s. 60-61) söz konusu Kurum'da vekâleten görevlendirilen yönetici personel oranının \% 44 olduğu tespit edilmiş, merkez teşkilatında bu oran \% 70 olarak belirlenmiştir. 2019 yılı Spor Toto Teşkilat Başkanlığı Sayıştay Denetim Raporu'nda (s. 13) fakülte veya yüksekokul 
mezunlarının atanabileceği bazı şube müdürlüklerine lise mezunu personelin vekâleten atandığı tespit edilmiştir. Sayıştay 2018 yılı Kalkınma Ajansları Genel Denetim Raporu'nda kalkınma ajanslarında genel sekreterlik ve birim yöneticiliği kadrolarına asaleten görevlendirme yapılması yerine vekâleten görevlendirme yolunun seçildiği, denetim yapıldığg tarih itibariyle 26 ajansın 13’ünde genel sekreterlik görevinin vekâleten yürütüldüğü tespit edilmiştir.

Sayıştay tarafından üniversite ve belediyelerde yapılan denetimlerde de vekâleten görevlendirmelerle ilgili problemler tespit edilmiştir. Kahramanmaraş Sütçü İmam Üniversitesi, Siirt Üniversitesi ve Süleyman Demirel Üniversitesi 2019 yılı Sayıştay denetim raporlarında bazı fakültelerin dekanlarının asaleten atamalarının yapılmayarak görevlerin vekâleten yürütüldüğü belirtilmiştir. Necmettin Erbakan Üniversitesi 2019 yılı Sayıştay Denetim Raporu'nda ise genel sekreter olarak atanan kişinin aynı gün genel sekreter yardımcılığı kadrosuna vekâleten atandığı, aynı tarihte genel sekreter olmak için gereken kamu hizmeti şartını taşımayan başka bir kişinin ise dolu olan genel sekreterlik kadrosuna "Tedviren" atandığı belirtilmiştir. Sayıştay denetçileri tarafından bazı belediyelerde mevzuat hükümlerine aykırı olarak sözleşmeli statüdeki personelin müdür kadrolarına vekâleten görevlendirildiğii, ${ }^{7}$ bazı belediyelerde ise dolu olmasına rağmen müdür kadrolarına vekâleten veya tedviren personel görevlendirildiği tespit edilmiştir. ${ }^{8}$

Liyakat ilkesi kapsamında tartışmaya açık diğer bir konu kamu personelinin statüsünün değiştirilmesine yönelik yapılan düzenlemelerdir. Türk kamu personel sisteminde genel eğilim statü hukukuna dayalı güvenceli istihdamdan uzaklaşarak sözleşmeli ve esnek istihdamın yaygınlaşması yönünde olmakla beraber, kimi zaman bu eğilimin tam tersi düzenlemeler de yapılmıştır. Bu tür düzenlemelerden bazıları şunlardır:

1984 yılında 241 sayılı KHK ile 657 sayılı DMK’ye ek geçici madde eklemek suretiyle; sürekli işçi ve sözleşmeli personel statüsündeki personel sınav şartı aranmaksızın boş memur kadrolarına geçirilmiştir.

2003 y1lında 4958 sayıl1 "Sosyal Sigortalar Kanunu" ile yapılan düzenleme kapsamında söz konusu Kurumda sözleşmeli olarak çalışan personel sınava tabi tutulmadan boş memur kadrolarına atanmışlardır.

\footnotetext{
${ }^{7}$ Hatay Büyükşehir Belediyesi, İstanbul Esenler Belediyesi, İstanbul Eyüpsultan Belediyesi, İstanbul Gaziosmanpaşa Belediyesi, İstanbul Kâğıthane Belediyesi, Sakarya Büyükşehir Belediyesi, Sakarya Su ve Kanalizasyon İdaresi Genel Müdürlüğü 2019 yılı Sayıştay düzenlilik denetim raporları.

${ }^{8}$ İstanbul Eyüpsultan Belediyesi, İstanbul Kâğıthane Belediyesi, İstanbul Şişli Belediyesi 2019 yılı Sayıştay düzenlilik denetim raporlar1.
} 
- 2007 yılında 5620 sayılı Kanun kapsamında kamu kurum ve kuruluşlarında görev yapan geçici işçiler sürekli işçi kadrolarına ya da sözleşmeli personel pozisyonlarına geçirilmiştir.

2011 yılında 632 sayılı KHK ile 657 sayılı DMK'ye eklenen geçici maddeyle, kamu kurum ve kuruluşlarının merkez ve taşra teşkilatı ile bunlara bağlı döner sermayeli kuruluşlarda sözleşmeli personel pozisyonlarında çalışan personel memur kadrolarına geçirilmiştir.

2013 yılında 6495 sayılı Kanun ile 657 sayılı DMK'ye eklenen geçici maddeyle, kamu kurum ve kuruluşlarının merkez ve taşra teşkilatı ile bunlara bağlı döner sermayeli kuruluşlarda; il özel idaresi, belediye ve bağlı kuruluşları ile mahallî idare birliklerinde ve TRT'de sözleşmeli personel pozisyonlarında görev yapan personel memur kadrolarına geçirilmiştir.

2017 yılında 696 sayılı KHK ile 375 sayılı KHK'ye geçici maddeler eklemek suretiyle yapılan düzenleme kapsamında, merkezi yönetimde çalışan yaklaşık 400.000 taşeron personel sürekli işçi kadrolarına; yerel yönetimlerde çalışan yaklaşık 450.000 taşeron personel ise belediye şirketlerinde işçi statüsüne geçirilmiştir. Bu sayı 2017 yılı sonu itibariyle kamuda görev yapan yaklaşık 3.600.000 personelin \% 24'ü kadardır.

Bu tür statü değişikliklerini bir çeşit sınavsız kamuda istihdam yöntemi olarak nitelemek mümkündür. Şöyle ki memuriyet kadrolarına geçirilen sözleşmeli statüdeki personelin bir kısmı sınava tabi tutulmadan kamuda işe girmişlerdir. Kamuda sözleşmeli personel çalıştırılmasına yönelik esaslar 1978 yılında 7/15754 sayılı Bakanlar Kurulu Kararı ile düzenlenmiş olmakla birlikte, sözleşmeli personel için sınav şartı 2007 yılında Bakanlar Kurulunun 2007/12251 sayılı kararıyla getirilmiştir. Bu noktada sözleşmeli personel çalıştırılmasına ilişkin esasların belirlenmesine yönelik düzenlemenin sadece DMK'nin 4/B maddesi kapsamında istihdam edilen sözleşmeli personeli kapsadığını ifade etmek gerekir. Oysa farklı mevzuata tabi değişik statülerde sözleşmeli personel istihdamı mevcuttur.

4857 sayılı İş Kanunu'na uygun olarak alt işverenlik uygulaması kapsamında kamuda istihdam edilen taşeron personel de sınava girmeksizin kamuda görev yapmaya başlamakta, devamında 2017 yılında olduğu gibi kadrolu kamu personeli statüsüne geçebilmektedir. Her ne kadar bu personel düzenleme kapsamında kadroya geçiş esnasında bir sınava tabi tutulmuş olsa da, söz konusu sınav daha ziyade prosedür gereği yerine getirilen bir uygulama niteliğinde olmuştur. 
Sürekli işçi kadrolarına alınacak personel için merkezi sınavda başarılı olma şartı 1999 yılında 99/12378 sayılı Bakanlar Kurulu Kararı ile getirilmiştir. Geçici işçi statüsünde istihdam için ise sınav şartı bulunmamaktadır. Ancak Sekizinci Beş Yıılık Kalkınma Planı'na yönelik olarak hazırlanan "Yerel Yönetimler Özel İhtisas Komisyonu Raporu”nda (s. 78, 80) memurlar tarafindan yerine getirilmesi gereken asli ve sürekli kamu hizmetleri de dâhil olmak üzere tüm görevlerin işçilerle birlikte "geçici işçi" statüsündeki personel tarafından da yerine getirildiği belirtilmiştir. Aynı Rapor'da yerel yönetimlerde geçici iş ve işçilik uygulamalarının amacını aşarak, kolay iş bulma, güvencesiz ve düşük maliyetli personel istihdam etme, yandaşları işe alma gibi boyutlara ulaştığı ifade edilmiştir. 2007 yılında 5620 sayılı Kanun'la, geçici iş pozisyonlarında işçi çalıştırılması ile ilgili hususlar yeniden düzenlenmiştir. Söz konusu Kanun'la, mevsimlik ve kampanya işleri ile orman yangınıyla mücadele hizmetlerinde bir malî yılda altı aydan az olmak üzere vize edilecek iş pozisyonlarında işçi çalıştırılabileceği, bunun dışında kamu kurum ve kuruluşlarında geçici iş pozisyonlarında işçi çalıştırılamayacağı hüküm altına alınmıştır. Düzenlemeyle, kamu kurum ve kuruluşlarında geçici işçi statüsünde görev yapmakta olan personel Kanun'da belirtilen esaslara uygun olarak sürekli işçi veya sözleşmeli personel pozisyonlarına geçirilmiştir.

Hizmete alma aşamasına yönelik problem sahaları kapsamında diğer bir husus kamu görevine alınacak personelin belirlenmesinde merkezi sınav sisteminin ağırlığının azalmasıdır. On Birinci Kalkınma Planı’na yönelik hazırlanan “Kamuda İnsan Kaynakları Çalışma Grubu Raporu"nda (s. 17) da merkezi sınava dayalı merkezi yerleştirme sisteminden uzaklaşıldığı, öğretmen atamalarının da merkezi yerleştirme yerine merkezi sınava dayalı kurumsal sözlü sınavla yapılmaya başlanması neticesinde merkezi yerleştirmeye dâhil memur sayısının oldukça azaldığg belirtilmiştir.

2002 yılında yürürlüğe giren Kamu Görevlerine İlk Defa Atanacaklar İçin Yapılacak Sınavlar Hakkında Genel Yönetmelik’te kadrolar (A) ve (B) olmak üzere iki ayrı gruba ayrılmıştır. (A) grubu kadrolar meslek memurluğu olarak da adlandırılan, “özel yarışma sınavına tabi tutulmak suretiyle girilen ve belirli bir yetişme programı sonrası yeterlik sinavına tabi tutulan mesleklere ilişkin kadro ve görevler ile il özel idareleri ve belediyelerin teftiş kurulları" kadrolarıdır. (A) grubu dışında kalan kadrolar ise (B) grubu olarak kabul edilmekte olup bu kadrolar normal memurluk kadroları olarak da nitelendirilebilinir. Yönetmeliğin ilk hâlinde (B) grubu kadrolara yapılacak yerleştirmelerin sadece merkezi sınav sonuçları esas alınarak yapılması öngörülmüştür. (A) grubu kadrolar için ise merkezi sınav bir ön sınav özelliğinde olup bu görevlere alınacaklar kurumlar tarafından yapılacak yazılı ve/veya sözlü 
sınav sonuçlarına göre belirlenmektedir. ${ }^{9}$ Yönetmeliğin üçüncü maddesinde istisnalar belirtilmiş olup 2014-2020 yılları arasında yapılan ilâvelerle istisnai kurum ve görevlerin sayısı artmıştır. Bununla beraber Yönetmeliğin kapsamı ile ilgili asıl önemli değişiklik 2006 yılında mahallî idarelere yönelik yapılmıştır. Bakanlar Kurulunun 11 Aralık 2006 tarihli ve 2006/11473 sayılı kararı ile il özel idareleri ve belediye kadrolarına atanacakların seçilmesi ile ilgili hususlar ayrı bir bölüm olarak Yönetmeliğe eklenmiş, ayrıca mahallî idarelere ait (B) grubu kadrolar merkezi sınav sonuçlarına göre yerleştirme uygulamasının dışına çıkarılmıştır. Değişiklik kapsamında mahallî idarelere atanacak memurlar KPSS sınavına ilave olarak ilgili kurum tarafindan yapılacak yazılı ve/veya sözlü sınav sonucuna göre belirlenecektir.

2006 yılındaki düzenlemede mahallî idareler tarafından yapılacak kurumsal sınava çağrılacak aday sayısı atama yapılacak kadro sayısının üç katı olarak belirlenmişken, 11 Eylül 2017 tarihli ve 2017/10785 sayılı Bakanlar Kurulu Kararı ile bu oran atama yapılacak kadro sayısının beş katına çıkarılmıştır. Mahallî idarelere ait kadroların diğer (B) grubu kadrolardan ayrılmasını ve daha sonrasında kurumsal sınava çağrılacak aday sayısının artırılmasını kayırmacılık uygulamaları için alan açmak olarak değerlendirmek mümkündür. Nitekim Danıştay Onikinci Dairesi Esas:2007/412 ve Karar:2010/1680 sayılı kararında mahallî idarelerin merkezi sınav dışında ayrıca sınav yapmasını hukuka aykırı bulmuştur. Kararın gerekçesi:

“(B) grubu kadrolara memur atamalarında adayların eşit koşullarda yarışmasını sağlayan objektif bir yöntem olan merkezi sinav yapılmasının yeterli görüldü̈̆̈̈ anlaşıldı̆̆ı̆ıdan, il özel idareleri ve belediyeler, bunlara bağlı kuruluşlarla kurdukları birlikler ve döner sermayeli kuruluşların (B) grubu kadrolarına memur atamalarında, adayların eşit koşullarda yarışmalarını sağlayan nesnel bir yöntem olan merkezi sınavdan sonra her türlü öznel değerlendirmeye açık bulunan ikinci bir sınavın yapılması, merkezi sınavın nesnel sonuçlarını kısmen dahi olsa etkisiz kılacă̆ gibi, bu sınavın sözlü yapılması hâlinde de sınavın yargısal denetimi yetki ve şekil unsurlarıyla sınırlandırılmış olacağından, sözü edilen (B) grubu kadrolara atamada diğer (B) grubu kadrolardan farklı olarak ikinci bir sinav yapllmasının subjektif değerlendirmelerin oluşabilmesine yol açıcı etkileri bulunduğu, eşitlik ilkesine ve hukuka aykırı olduğu” olarak ifade edilmiştir.

Danıştay Onikinci Dairesinin kararı doğrultusunda Yönetmelik’te mahallî idarelerle ilgili yapılan değişiklikler iptal edilmiş, ancak Danıştay Onikinci Dairesinin 2010 yılında

\footnotetext{
${ }^{9}$ Yönetmeliğe göre kendi mevzuatında hüküm bulunmak kaydıyla kamu kurum ve kuruluşları tarafından sadece KPSS puanı esas alınmak suretiyle de (A) grubu kadrolara atama yapılabilmesi mümkündür.
} 
verdiği karar, Danıştay İdari Dava Daireleri Kurulunun 06 Şubat 2014 tarihli, Esas:2010/2803 ve Karar:2014/271 sayılı kararı ile bozulmuş, dolayısıyla yapılan değişiklikler tekrar yürürlüğe girmiştir. Bu noktada Danıştay İdari Dava Daireleri Kurulunun, Karar'ı bozma gerekçesinin mahallî idareler tarafından ayrıca sınav yapılmasının hukuki olarak uygun olup olmadığı ile ilgili olmadığının vurgulanması gerekir. Danıştay Onikinci Dairesinin ilgili Karar’ının iptal gerekçesi söz konusu davayı açan Türkiye Kamu Çalışanları Sendikaları Konfederasyonunun Yönetmelik değişikliğine karşı dava açma ehliyetinin olmaması olarak ifade edilmiştir. Yönetmeliğin son hâline göre ise mahallî idareler boş bulunan memur kadrolarına merkezi yerleştirme yoluyla ya da kurumsal sınavla açıktan atama yapabilmektedirler.

Mahallî idarelerle ilgili yapılan düzenlemelere ilave olarak Yönetmeliğe ek maddeler eklemek suretiyle merkezi yönetime ait kadrolarla ilgili de değişiklikler yapılmıştır. Bu kapsamda 2006 yılında Yönetmelik’te yapılan değişiklikle öğretmenlerin ilk atamalarının KPSS sınavından alınan puanın \%50'si ile Milli Eğitim Bakanlığınca yapılan alan seçme sınavından alınan puanın \%50'si esas alınarak Bakanlık tarafından yapılacağı, öğretmen ihtiyacı durumuna bağlı olarak sadece KPSS sonucuna göre de yerleştirme işlemi yapılabileceği hükmü getirilmiştir. Yönetmeliğe ilave edilen ek maddelerle; 2012 yılında hazine avukatı ve hukuk müşaviri kadroları ile avukat kadro ve pozisyonları, 2013 yılında orman muhafaza memuru kadroları, 2014 yılında Devlet Su İşleri Genel Müdürlüğü ve Orman Genel Müdürlüğü mühendis kadroları, 2019 yılında ise Türkiye Adalet Akademisinin koruma ve güvenlik görevlisi kadroları (B) grubu olmasına rağmen merkezi yerleştirmeye tabi kadrolardan çıkarılmış, bu kadrolara KPSS sınavını müteakip ilgili kurum tarafından yazılı/sözlü/uygulamalı sınav ile alım yapılacağı belirtilmiştir. 2006-2019 yılları arasında yapılan bu değişikliklerin bir kısmı Danıştay tarafından tamamen veya kısmen iptal edilmiştir.

Görüldüğü üzere Kamu Görevlerine İlk Defa Atanacaklar İçin Yapılacak Sınavlar Hakkında Genel Yönetmelik’te yapılan değişikliklerle başlangıçta öngörülen ana düşünceden oldukça uzaklaşılmış, kamu görevine alımlarda kurumlar tarafından yapılan sınavların belirleyiciliği artırılmıştır. Oysa liyakat ilkesi kapsamında en çok eleştirilen husus kurumlar tarafından yapılan sözlü sınav ve mülakatların eleme aracı olarak kullanılması, başta partizan atamalar olmak üzere bu sınavlarda kayırmacılık uygulamalarının yapılmasıdır.

Sözlü sınavlara yönelik yapılan eleştirilere çözüm olarak, bahse konu sınavların kayıt altına alınmasının yanında, sözlü sınavların/mülakatların hiç yapılmayarak personelin merkezi sınav sonuçlarına göre yerleştirilmesi de önerilmektedir. Bazı siyasi parti programlarında 
mülakat uygulamasına son verileceği ifadesi yer almaktadır. ${ }^{10} \mathrm{Bu}$ konuda Anayasa Mahkemesinin 2013 yılında aldığı Esas:2011/21, Karar:2013/36 sayılı kararın incelenmesi faydalı olacaktır. Cumhuriyet Halk Partisi TBMM Grubu adına 6085 sayılı Sayıştay Kanunu'nun bazı maddelerinin iptaline yönelik Anayasa Mahkemesine açılan davada diğer maddelerle birlikte "Sayıştay denetçilerinin nitelikleri ve mesleğe alınmaları" başlıklı 17'nci maddenin de bazı bölümlerinin iptali yönünde başvuruda bulunulmuştur. $\mathrm{Bu}$ kapsamda, "Ö̈güveni, ikna kabiliyeti ve inandırıcılı̆̆l”, "Genel yetenek ve genel kültürü" ve "Bilimsel ve teknolojik gelişmelere açıklı̆ğ" ifadelerinin mülakat esnasında adayın değerlendirileceği hususlardan çıkarılması talep edilmiştir. Bunun yanında "Bunun dışında mülakat ile ilgili herhangi bir kayıt sistemi kullanılmaz." ile "Mülakatta başarılı sayılmak için, komisyon başkan ve üyelerinin yüz tam puan üzerinden verdikleri puanların aritmetik ortalamasının en az yetmiş olması şarttır." cümlelerinin de iptali istenmiştir. Dava dilekçesinde, yazılı sınavın nesnelliği ile mülakat sınavının öznelliğine vurgu yapılmış; mülakata 70 puan barajı getirmenin, eleme ve yazılı sınavın nesnel sonuçlarını ortadan kaldırma işlevini yerine getirmenin yanında, bu totolojiyi matematiksel bir kesinliğe taşıyarak mülakat komisyonunu vicdani rahatlığa kavuşturma işlevi gördüğü ifade edilmiştir.

Anayasa Mahkemesi, eşitlik ilkesinin amacının aynı durumda bulunan kişilerin kanunlar karşısında aynı işleme bağlı tutulmalarını sağlamak olduğunu vurgulayarak, yapılan düzenlemenin kanun koyucunun takdir yetkisinde olduğu gerekçesiyle iptal başvurusunu reddetmiştir. "Bunun dışında mülakat ile ilgili herhangi bir kayıt sistemi kullanılmaz." cümlesinin iptali ise, kuralın mülakata giren tüm kişiler için geçerli genel ve objektif bir düzenleme olması ve kamu hizmetine girmeyi engelleyici bir özellik taşımaması gerekçesiyle oy çokluğuyla reddedilmiştir. Anayasa Mahkemesi, “mülakat veya sözlü sınavların kamerayla kayıt altına alınarak yargısal denetimin daha kolay bir şekilde yapılabilmesine olanak tanınması" yönündeki değerlendirmenin ise anayasal denetimde bağlayıcılığının olmadığını belirtmiştir. Bu noktada Yüksek Mahkemenin konuyu Anayasa'ya uygunluk açısından değerlendirdiğini vurgulamak gerekir. Ancak sözlü sınavların/mülakatların adil olarak yapılmadığı, eleme amaçlı kullanıldığı, kamuda siyasi kadrolaşmaya olanak sağladığı yönünde eleştiriler sık sık kamuoyunda gündeme gelmektedir. Sözlü sınavlarda ve mülakatlarda yaşanan kayırmacılık uygulamalarına yönelik eleştiriler işçi ve sözleşmeli personel alımları için de geçerlidir. Bunun yanında sözleşmeli personel çalıştırılmasına yönelik esaslarla ilgili mevzuatta

\footnotetext{
${ }^{10}$ Deva Partisi, Gelecek Partisi parti programlarında mülakat uygulamasına son verileceği, Saadet Partisi parti programında ise öğretmen alımlarında mülakat uygulamasının kaldırılacağı belirtilmektedir.
} 
2009 yılında yapılan değişiklikle, KPSS notuna göre kurumlar tarafından yapılacak yazılı ve/veya sözlü sınava çağrılacak personel sayısı alım yapılacak pozisyon sayısının beş katından on katına çıkarılmıştır.

Sözlü sınavlara yönelik bu eleştirilerin yanında bir görüşe göre hem (A) grubu kadrolar hem de (B) grubu kadrolara atanacak kişilerin görevin gerektirdiği niteliklere sahip olup olmadığının sadece merkezi sınav ile belirlenmesi mümkün değildir. Bu nedenle uygulamalı veya sözlü sınav yapılması bir gerekliliktir. (B) grubu kadrolara yönelik merkezi sınavların sadece kişinin genel yetenek ve genel kültür seviyesinin tespit edilmesine yönelik olması ve her bir meslek için alan bilgisini ölçen sınavların yapılamıyor olması da bu değerlendirmeyi güçlendirmektedir. Bu değerlendirme esas alındığında merkezi sınav uygulaması kişinin görev için yeterliliğini ölçmekten ziyade adaletin sağlanması yönünde bir fonksiyonu yerine getirmektedir.

Kurumsal sınavların bir taraftan gerekli, diğer taraftan kayırmacılık uygulamalarına açık olduğu değerlendirildiğinde bu sınavların nesnelliğinin artırılmasına yönelik düzenlemeler yapılması ihtiyacı ortaya çıkmaktadır. Bu kapsamda sözlü ve uygulamalı sınavların da yazılı sınavda olduğu gibi mümkün olduğu oranda merkezi olarak yapılmasının incelenmesi faydalı olacaktır. Alanında uzman olan kişiler tarafından, objektif kriterler doğrultusunda merkezi olarak yapılacak sözlü ve uygulamalı sinavlar liyakate dayalı bir hizmete alma sisteminin tesisine katkı sağlayacaktır. Ancak sınavı kaybedenler de dâhil olmak üzere tüm adayların sınav heyetinin tarafsız ve adaletli davrandığına tam olarak inanması liyakat ilkesi açısından önem arz etmektedir. Bu kapsamda sinav heyetlerinde görev alacak üyelerin siyaseten tarafsız ve konunun uzmanı kişiler arasından seçilmesi, siyasi ve üçüncü kişilerden gelebilecek baskılara karşı güvenceler sağlanması, sınavların kayıt altına alınması da dâhil olmak üzere şeffaflıkla ilgili gerekli tedbirlerin alınması oldukça önemlidir.

\subsection{Değerlendirme Sistemi}

Personel değerlendirmesinde yaygın olarak kullanılan iki sistemden birisi sicil değerlendirmesi iken diğeri performans değerlendirmesidir. Türk kamu personel sisteminde sicil değerlendirme sistemi benimsenmiş olmakla beraber sık sık performans değerlendirme sistemine geçilmesi ihtiyacı gündeme getirilmiştir. Yedinci Beş Yıllık Kalkınma Planı’nda (1996-2000), üst kademe kamu yöneticilerinden gerekli performansı gösteremeyenlerin diğer kamu görevlerine nakledilmelerinin sağlanacağı, kamu kurum ve kuruluşlarının hizmet üretimine yönelik çalışmalarının proje çalışması şeklinde yürütülmesinin esas olacağı ve çalışanların performansının projeden elde edilecek sonuca göre değerlendirileceği ifade 
edilmiştir. Sekizinci Beş Yıllık Kalkınma Planı’nda (2001-2005), çalışanların performansını etkin bir şekilde ölçen bir sistemin tesis edilmesi kamu yönetiminin iyileştirilmesi ve yeniden yapılandırılması kapsamında temel ilkelerden biri olarak belirlenmiştir. Dokuzuncu Kalkınma Planı'nda (2007-2013), personel değerlendirme sisteminin gözden geçirileceği, personel performansını objektif ve saydam biçimde ölçmeyi sağlayacak standartlar geliştirileceği ve uygulanacağı ifade edilmiştir. Onuncu Kalkınma Planı'nda (2014-2018), kamu personelinin verimliliğinin artırılması amacıyla etkin bir performans sisteminin oluşturulması kamuda insan kaynakları yönetiminde uygulanacak politikalardan biri olarak belirlenmiştir. ${ }^{11}$

Türk kamu personel sisteminde 1879 yılından itibaren uygulanan sicil sistemi 13 Şubat 2011 tarihinde kabul edilen 6111 sayılı Kanun ile kaldırılmıştır. Ancak sicil sistemi performans değerlendirme sistemine geçmek amacıyla kaldırılmamıştır. Sicil sisteminin kaldırılmasına giden süreç 2003 yılında 4982 sayılı “Bilgi Edinme Hakkı Kanunu”nun yürürlüğe girmesi ile başlamıştır. Kanun'un yürürlüğe girmesini müteakip “Bilgi Edinme Değerlendirme Kurulu” tarafından özlük dosyaları ve sicil raporlarının ilgili kamu görevlisine karşı açık olması gerektiği yönünde verilen karar neticesinde sicil raporları alenilik kazanmıştır. Danıştay tarafindan da yetkili sicil amirlerinin kanaatinin oluşmasına etki eden hususların somut bilgi ve belgeye dayandırılmasının bir zorunluluk olduğunu belirten kararlar verilmesi neticesinde (Saydam, 2018, ss. 78-79) sicil sistemi işlerliğini kaybetmiştir. Nitekim 657 sayılı DMK'deki sicil ile ilgili maddenin kaldırılma gerekçesi şu şekilde ifade edilmiştir: ${ }^{12}$

"Yıllardır süren uygulamalar, Devlet memurları için gizli sicil raporu doldurulması suretiyle başarı ve başarısızlığın tespitinin mümkün olamadığını göstermiştir. 4982 sayılı Bilgi Edinme Hakkı Kanunu kapsamındaki başvurularla birlikte, gizli olması gereken sicil raporlarının aleniyet kazanması, çalışanlar ile idarecileri karşı karşıya getirmiş, bu alandaki idarî yargı davalarında büyük bir artışa yol açmıştır. Özellikle yıl sonunun gelmesiyle sicil amirleri açısından bir külfet hâlini alan sicil değerlendirmesi, memurların yükselmesinde ve liyakatin tespitinde başlıca dayanak olma vasfinı yitirmiş, bürokratik bir formaliteye dönüşmüşı̈̈r. Gelinen noktada, gerek değerlendirme makamlarl, gerekse değerlendirilenler açısından inandırıcılığını ve güvenilirliğini yitirmiş olan sicil sisteminin kaldırılmasının kamu yararı açısından daha uygun olacă̆ı değerlendirilmektedir."

\footnotetext{
${ }^{11} \mathrm{Kamu}$ personelinin değerlendirilmesinde performans sistemine geçilmesine yönelik yapılan çalışmalar ile performans sisteminin sicil sistemiyle karşılaştırılması kapsamında bkz. (Sayan ve Demirci, "Kamu Personelinin Değerlendirilmesinde Performans Sistemine Geçiş Sürecinin Analizi”, 2018)

${ }^{12} \mathrm{https} / / /$ www.tbmm.gov.tr/sirasayi/donem23/yil01/ss606.pdf (Erişim:14.04.2021)
} 
Kaldırılan sicil sistemi yerine yeni bir değerlendirme sistemi tesis edilmesi görevi Devlet Personel Başkanlığına verilmiştir. Başkanlık tarafından performans değerlendirme sistemini esas alan ancak "performans" yerine "başarl" kelimesinin kullanıldığ 1 (Saydam, 2018, s. 90) “Kamu Personelinin Başarılarının Değerlendirilmesine İlişkin Genel Yönetmelik Taslağı” 2017 yılında kamuoyu ile paylaşılmıştır. Kamu kurum ve kuruluşları ile kamu görevlileri sendikaları konfederasyonları temsilcileri ve akademisyenlerin katılımıyla taslak Yönetmelik'le ilgili toplantılar yapılmış ancak çalışmalar neticelendirilmemiştir. Mevcut durum itibariyle tüm kamu personelini kapsayan bütüncül bir değerlendirme sistemi mevcut olmamakla birlikte DMK'nin 122'nci maddesinde kamu kurum ve kuruluşlarına verilen yetki kapsamında ${ }^{13}$ bazı kamu kurum ve kuruluşları kendi özel mevzuatlarına uygun olarak personel değerlendirmesi yapmaktadırlar. Bununla beraber aradan on yıl geçmesine rağmen kaldırılan sicil sistemi yerine tüm kamu personeli için geçerli olacak yeni bir değerlendirme sisteminin tesis edilememiş olması liyakat ilkesi kapsamında önemli bir eksikliktir.

\subsection{Kamu Personelinin Eğitimi}

Liyakate dayalı kamu personel sisteminin gereklerinden birisi de kamu personeline etkin bir eğitim verilmesidir. Eğitimin önemi kalkınma planlarında da önemle vurgulanan hususlardan biri olmuştur. Bununla beraber, kalkınma planlarının birçoğunda kamu yönetim sisteminin kalkınmayı destekleyecek etkinlik ve verimlilikte olmadığı belirtilmiş, aynı zamanda başta yönetici personel olmak üzere kamu personelinin yetersizliğine vurgu yapılmıştır. Bu kapsamda gerek genel eğitim, gerekse hizmet içi eğitimin geliştirilmesi ihtiyacı birçok planda ifade edilmiştir.

Teknolojideki gelişmelere paralel olarak eğitim ihtiyaçları ve eğitimin uygulanma şekilleri de değişmektedir. Nitekim 2019-2023 yıllarını kapsayan On Birinci Kalkınma Planı'nın “Kamuda İnsan Kaynakları” bölümünde kamu personeline verilen eğitimlerin çeşitlendirileceği ve geliştirileceği, her düzeydeki personele yönetim becerisi kazandırmayı amaçlayan eğitim programları geliştirileceği, hizmet içi eğitimde uzaktan eğitim sistemlerinin kullanılacağı ve kamu personelinin dijital becerilerinin geliştirileceği ifade edilmiştir. Ancak planlarda bu ifadeler yer almakla birlikte eğitim ile ilgili faaliyetlerin hangi etkinlikte yerine getirildiği tartışmalıdır.

\footnotetext{
13 "Kamu kurum ve kuruluşları yürütmekte oldukları hizmetlerin özelliklerini göz önünde bulundurarak memurlarının başarı, verimlilik ve gayretlerini ölçmek üzere, Devlet Personel Başkanlığının uygun görüşü alınmak kaydıyla, değerlendirme ölçütleri belirleyebilir."
} 
Devlet memurlarının yetiştirilmesi ile ilgili hususlar 657 sayılı DMK'nin 214-225'inci maddelerinde, aday memurların yetiştirilmesine yönelik esaslar ise Kanun'un 55'inci maddesinde açıklanmıştır. Bu kapsamda devlet memurlarının yetiştirilmesi ile ilgili en önemli sorumluluk Devlet Personel Başkanlığına verilmiştir. 657 sayılı DMK'de Devlet Personel Başkanlığının kurumların eğitim programlarının hazırlanmasında ve uygulanmasında yol göstermek, yetiştirme faaliyetlerini koordine etmek ve denetlemekle görevli olduğu; hizmet içi eğitimin Devlet Personel Başkanlığı tarafından ilgili kurumlarla birlikte hazırlanacak yönetmelikler dâhilinde yürütüleceği; kurumlar tarafından yürütülen eğitim çalışmalarına ait raporların Devlet Personel Başkanlığına gönderileceği belirtilmiştir. 2018 yılı Temmuz ayında yayımlanan 703 sayılı KHK ile Devlet Personel Başkanlığının bir yıl süreyle görevine devam edeceği, bu sürenin bitiminde Başkanlığın kapanmış sayılacağı belirtilmiştir. Kamu personelinin eğitimiyle ilgili diğer bir önemli kurum olan TODAİE de 703 sayılı KHK ile kapatılmış, Kurumun her türlü araç, gereç, taşınır, taşınmaz, yayın, yayın hakları, kurumsal belge ve arşiviyle birlikte Ankara Hacı Bayram Veli Üniversitesine devredilmiştir. Geçmiş dönemde TODAİE tarafından yerine getirilen görevlerin hangi kurum tarafından yerine getirileceğine yönelik bir düzenleme de yapılmamıştır.

Kapatılan TODAİE'nin yerine kamu yönetim sisteminin geliştirilmesi ile ilgili çalışmalar yapma ve kamu personelinin eğitimi faaliyetlerini merkezi olarak yürütme ve koordine etme görevini yerine getirmek üzere "Kamu Yönetimi Akademisi” kurulması konusunun incelenmesinin faydalı olacağı değerlendirilmektedir. ${ }^{14}$ Fransız Ulusal Yönetim Okulu ENA örneğinde olduğu gibi Kamu Yönetimi Akademisinin liyakat ilkesi kapsamında önemli bir fonksiyona sahip olması da mümkündür. Birçok Fransız Cumhurbaşkanı, Başbakan ve üst düzey kamu yöneticisini yetiştiren ENA aynı zamanda bir hizmete alma ve seçme organı olarak da faaliyet göstermektedir. ENA örneğinde olduğu üzere Kamu Yönetimi Akademisine de üst kademe kamu yöneticilerinin eğitilmesinin yanında belirlenmesine yönelik de bir takım yetkiler verilmesi söz konusu yöneticilerin belirlenmesindeki "belirsizlik" ve “ölçüsüzlük" problemini gidererek liyakat ilkesinin uygulanmasına önemli ölçüde katkı sağlayacaktır.

\footnotetext{
${ }^{14}$ Sekizinci Beş Yıllık Kalkınma Planı hazırlıkları kapsamında hazırlanan "Kamu Yönetiminin İyileştirilmesi ve Yeniden Yapılandırılması Özel İhtisas Komisyonu Raporu”nda da TODAİE’nin tüm kamu yönetimine eleman yetiştirecek şekilde Kamu Yönetimi Akademisine dönüştürülmesi önerilmiştir. 2021 yılı Mart ayında yapılan KPDK toplantısında Türkiye KamuSen Konfederasyonu tarafından önerilen hususlardan birisi de "yönetici akademisi" kurularak yöneticilerin bu kurumda yetiştirilmesi, böylelikle kamu kurumlarında hak edenlerin hak ettiği mevkilere eğitim verilerek yerleştirilmesinin sağlanması olmuştur. (https://www.kamusen.org.tr/genel-haberler/kpdk-toplantisinda-sozlesmelilere-kadro-icin-onemli-bir-adimatildi/4656/) (Erişim:14.04.2021). Üst kademe kamu yöneticilerinin yetiştirilmesine yönelik olarak 2004 yılında Ömer Faruk Günay tarafindan "Üst düzey kamu yöneticilerinin yetiştirilmesi" isimli doktora tezi hazırlanmış ve bir model önerisi sunulmuştur.
} 
1965 yılında yürürlüğe giren 657 sayılı DMK'de, Devlet Personel Dairesi tarafından Maliye Bakanlığı, Millî Eğitim Bakanlığı, TODAİE, Devlet Planlama Teşkilatı ve ilgili kurumların görüşleri de alınarak “Devlet Memurları Eğitimi Genel Planı"nın hazırlanacağı belirtilmiştir. "Devlet Memurları Eğitimi Genel Planı" ancak 1983 yılında yürürlüğe girebilmiştir. 1983 yılında ayrıca “Aday Memurların Yetiştirilmelerine İlişkin Genel Yönetmelik” yayımlanmıştır. Kamu kurum ve kuruluşlarında hizmet içi eğitim Devlet Personel Başkanlığınca hazırlanan ve 1984 yılında yürürlüğe giren "Hizmet İçi Eğitim Genel Planı" çerçevesinde yürütülmektedir.

Mevcut durum itibariyle gerek kamu personelinin eğitimine yönelik mevzuatın güncellenmemiş olması, gerekse kamu personelinin eğitimiyle ilgili konulardan sorumlu iki merkezi kurumun kapatılmasına rağmen bu kurumlar tarafından yerine getirilen görevlere yönelik yeni bir düzenleme yapılmamış olması liyakat ilkesi kapsamında önemli eksikliklerdir.

\subsection{Devlet Memurları Kanunu}

1961 Anayasası'nda memurlarla ilgili yer alan hükümlere uygun olarak 1965 yılında hazırlanan 657 sayılı DMK'de kamu personel sisteminin asli unsuru olarak kabul edilen memurların emekli olana kadar tarafsız ve sadakatle devlete hizmet etmeleri, bunun karşılığında gerekli mesleki güvencelere sahip olmaları öngörülmüştür. Devlet memurlarının siyaseten tarafsızlığına özel önem verilmiştir. Sözleşmeli statüde istihdamın, gerekli eğitimin ülke içinde verilemediği uzmanlık alanlarına yönelik ve geçici süreli olması ilkesi benimsenmiştir. 1965 yılından önce de mevcut olan istisnai memurluk kadroları korunmakla birlikte söz konusu kadrolara öncelikle DMK'ye tabi memurların atanması öngörülmüş, bunun dışında bu kadrolara atananların görevlerinden ayrıldıklarında hiçbir hak talebinde bulunamayacakları belirtilmiştir. İstisnai memurluklar dışındaki memurların Kanun'da belirtilen ilerleme ve yükselme şartlarına uygun olarak gerekli hizmet sürelerini tamamlamış olmaları, "Değerlendirme Kurulları" tarafindan sicil olarak yeterliliklerinin tespit edilmiş olması, yeterlik veya yarışma sınavında başarılı olmaları şartlarına bağlı olarak kariyer basamaklarında ilerleyip üst kademe görevlere yükselmeleri esas alınmıştır. Kanun’un ilk hâlinde "asansörle çıkma", "sıçrama", "paraşütleme" gibi adlarla tanımlanan olağandışı yükselme yöntemleri belirlenmemiş; istisnai memurluklar dışında üst kademe yöneticilik kadrolarına dışarıdan atanmaya yönelik bir düzenleme yapılmamıştır. Bir bütün olarak değerlendirildiğinde DMK'nin ilk hâlinde "tekleştirici”, "standartlaştırıcı" (Albayrak, 2020b, s. 1543) ve kapalı kariyer sistemini esas alan bir kamu personel sistemi öngörülmüştür. 
1982 Anayasası'nda memurlarla ilgili 1961 Anayasası'nda yer alan genel ilkeler korunmuştur. Ancak DMK için aynı şeyi söylemek mümkün değildir. Üzerinde yapılan birçok değişiklik neticesinde hem DMK'nin bütünlüğü bozulmuş, hem de başlangıçta belirlenen ana felsefeden oldukça uzaklaşılmıştır. Asli ve sürekli kamu hizmetlerinin memur statüsü dışındaki personel ve alt işverenlik uygulaması kapsamında özel sektör tarafından da yapılır hâle gelmesi, istisnai memurluk kadrolarının artması, üst kademe kamu yönetici kadrolarına daha önceden kamuda görev yapmamış kişilerin atanabilmesine yönelik yapılan değişiklikler kamu personel sistemini kapalı kariyer sisteminden uzaklaştırmıştır. Örneğin DMK'nin sözleşmeli personel ile ilgili 4/B maddesinde, sözleşmeli statüde istihdamın "zaruri ve istisnai hallere münhasır olmak üzere özel bir meslek bilgisine ve ihtisasina ihtiyaç gösteren geçici işlerde" olacağ1 belirtilmişken; bu cümlenin devamına, bu tanıma uymayan birçok pozisyonda sözleşmeli personel istihdam edilebilmesine yönelik ilaveler yapılmıştır. Dolayısıyla maddenin kendi içerisinde bir tutarsızlık mevcuttur. Bunun yanında birçok kanunda DMK'de belirtilen esaslara bağlı kalınmaksızın sözleşmeli personel istihdam edilebileceği belirtilmiştir.

Sözleşmeli statüde istihdamda olduğu gibi, kamu personel sisteminin diğer alanlarına yönelik düzenlemelerin bir kısmı da DMK üzerinden değil diğer kanunlarla yapılmaktadır. Örneğin başta kamu personelinin özlük haklarına yönelik hususlar olmak üzere memurlarla ilgili birçok önemli konu 375 sayılı KHK ile düzenlenmiş olup, kamu personel sistemi ile ilgili bazı yeni düzenlemeler de 657 sayılı DMK değil, 375 sayılı KHK'ye eklenerek yapılmaktadır. Bu durumda DMK'nin temel personel kanunu olma özelliği de bulunmamaktadır.

DMK, başlangıçta benimsenen ilkelerden uzaklaşılması, bütünlüğünün bozulmuş olması, birçok düzenlemenin başka kanunlar üzerinden yapılması nedeniyle kamu personel sisteminin ihtiyaçlarına cevap verebilecek nitelikte değildir. Hatta bazı değerlendirmelere göre Kanun'un kendisi kamu personel sisteminin en önemli sorunudur (Y1ldı, 2019, s. 415). Kanun'un yetersizliği 1970'li yıllardan itibaren kalkınma planlarında da gündeme getirilmiştir. Üçüncü Beş Yıllık Kalkınma Planı'nda (1973-1977) Kanun'un kendisinden beklenen iyileşmeyi sağlayamadığı, Dördüncü Beş Yı1lık Kalkınma Planı'nda (1979-1983) ise DMK'de yapılan değişikliklerin söz konusu Kanun'u büsbütün sistemsiz hâle getirdiği belirtilmiştir. Yedinci Beş Yıılık Kalkınma Planı'nda (1996-2000) DMK’nin yürürlükten kaldırılacağı, Sekizinci Beş Yıllık Kalkınma Planı'nda (2001-2005) ise tüm kamu personelini kapsayan tek bir kanunun çıkarılacağı ifade edilmiştir. Dokuzuncu Kalkınma Planı'nda (2007-2013) DMK'nin yerini almak üzere hazırlanan yeni personel kanununun çıkarılmasına yönelik 
faaliyetlerin devam ettiği ifade edilmiştir. Çeşitli tarihlerde yeni bir kamu personel kanunu hazırlama çalışmaları yapılmış olsa da hiçbiri hayata geçirilememiştir.

Mevcut durum itibariyle kamu personel sistemi ile ilgili temel esasları belirleyen bütüncül bir personel kanunu hazırlanması ihtiyacı devam etmektedir. Ancak olaya DMK'nin yeniden hazırlanması gözüyle bakılmaması gerekir. Öncelikle kamu personel sisteminin; istihdam şekilleri, memurlara sağlanan güvenceler, görevde ilerleme ve yükselmeler, üst kademe kamu yöneticileriyle ilgili hususlar, personel değerlendirme esasları gibi alt konularına yönelik genel esaslarının nasıl olacağının detaylı olarak çalışılması gereklidir. Bunun için de merkezi bir personel örgütünün hem bu çalışmaların eşgüdümünü sağlaması hem de devamında sisteme sahip çıkması gerekir. Yeni personel sisteminin ana esaslarının belirlenmesini müteakip öncelikle Anayasa'nın 128 ve 129'uncu maddelerinde yer alan kamu hizmeti görevlileriyle ilgili esasların yeniden ifade edilmesi ve diğer kamu görevlileri ifadesine açıklık getirilmesi, sonrasında yeni personel kanununun yürürlüğe konulması uygun olacaktır. Yeni hazırlanacak kanunun tüm kamu personelini kapsayacak şekilde bütüncül olması, liyakat sisteminin alt unsurlarının da belirlenip kanunda yer alması faydalı olacaktır. Sistemin ana esaslarının bu kanunda belirlenmesini müteakip bazı konularda yönetmeliklere atıf yapılması mümkündür. $\mathrm{Bu}$ durumda kanunun isminin de Devlet Memurları Kanunu değil Kamu Personeli Kanunu olması daha uygun olacaktır.

\section{Cumhurbaşkanlığı Hükümet Sistemine Geçiş Kapsamında Yapılan Değişiklikler}

16 Nisan 2017 tarihinde yapılan halkoylamasında "Türkiye Cumhuriyeti Anayasasında Değişiklik Yapılmasına Dair Kanun"un ${ }^{15}$ kabul edilmesi neticesinde parlamenter sistemden Cumhurbaşkanlığı Hükümet Sistemine geçilmiştir. Cumhurbaşkanlığı Hükümet Sistemine fiili olarak geçilmeden önce 02 Temmuz 2018 tarihinde Bakanlar Kurulu tarafından onaylanan 703 sayılı KHK ile devlet teşkilatı adeta dağıtılmış, müteakiben 1 sayılı Cumhurbaşkanlığı Kararnamesi ile sistem yeniden düzenlenmiştir (Turan, 2018, s. 81). Her ne kadar KHK'nin amacı Anayasa'da yapılan değişikliklere uyum sağlamak olarak ifade edilmiş olsa da Anayasa değişikliği ile ilgisi olmayan birçok konuda da çok önemli değişiklikler yapılmıştır. Düzenleme kapsamında birçok kanun yürürlükten kaldırılmış birçok kanun ve KHK'de ise önemli değişiklikler yapılmıştır.

703 sayılı KHK ile kamu personel sistemine yönelik yapılan değişikliklerin en önemlilerinden birisi Devlet Personel Başkanlığının kapatılmasıdır. Merkezi bir personel

\footnotetext{
${ }^{15}$ Kanun No.6771, RG:11.02.2017, Sayı:29976
} 
örgütünün gerekliliği 1960 yılından önceki dönemde yerli ve yabancı uzmanlar tarafından hazırlanan birçok raporda ifade edilmiş, nihayetinde 17 Aralık 1960 tarihinde 160 sayılı Kanun'la ${ }^{16}$ Devlet Personel Dairesi kurulmuştur. 08 Haziran 1984 tarihinde 217 say1lı "Devlet Personel Başkanlı̆̆ı Kuruluş ve Görevleri Hakkında Kanun Hükmünde Kararname" ${ }^{17}$ ile Başkanlığa dönüştürülen kurum kendisinden beklenen görevleri tam olarak yerine getirememiş, yetkilerinin birçoğunu Maliye Bakanlığı Bütçe ve Mali Kontrol Genel Müdürlüğü (BÜMKO) ile paylaşmak durumunda kalmıştır. ${ }^{18}$ Oral'a göre (2019, s. 458) kendisinden beklenenleri veremeyen Kurum kapatılmak suretiyle cezalandırılmıştır. Kurumun kapatılmasının nedenlerinden biri de siyasi iradenin kendi müdahale alanını daraltacak güçlü bir merkezi yapı karşısında isteksiz olmasıdır (Oral, 2019, s. 410).

703 sayılı KHK ile Devlet Personel Başkanlığının görev ve sorumluluklarını düzenleyen 217 sayılı KHK de yürürlükten kaldırılmış, söz konusu KHK'de Devlet Personel Başkanlığına verilen görev ve sorumlukların birçoğu 1 sayılı Cumhurbaşkanlığı Kararnamesi ile Aile, Çalışma ve Sosyal Hizmetler Bakanlığına verilmiştir. Bununla beraber yeni sistemde kamu personel sistemine yönelik görev ve sorumluluklar genel olarak Cumhurbaşkanlı̆̆ İnsan Kaynakları Ofisi; Cumhurbaşkanlığı Strateji ve Bütçe Başkanlığı; Cumhurbaşkanlığı İdari İşler Başkanlığı Personel ve Prensipler Genel Müdürlüğü; Aile, Çalışma ve Sosyal Hizmetler Bakanlığı Çalışma Genel Müdürlüğü arasında paylaşılmıştır. Ayrıca mahallî idareler personel sistemiyle ilgili olarak Çevre ve Şehircilik Bakanlığı ile İçişleri Bakanlığının bir takım yetki ve sorumlulukları bulunmaktadır.

21 Nisan 2021 tarihli ve 31461 sayılı Resmi Gazete'de yayımlanan 73 sayılı Cumhurbaşkanlığı Kararnamesi ile Aile, Çalışma ve Sosyal Hizmetler Bakanlığı; Aile ve Sosyal Hizmetler Bakanlığı ile Çalışma ve Sosyal Güvenlik Bakanlığı olmak üzere iki ayrı bakanlığa ayrılmıştır. Söz konusu Cumhurbaşkanlığı Kararnamesi ile kamu kurumlarının kamu personel sistemine yönelik görev ve sorumluluklarına yönelik mevzuatta da değişiklikler yapılmış, 2 sayılı Genel Kadro Usulü Hakkında Cumhurbaşkanlığı Kararnamesi’nde Devlet Personel Başkanlığına verilen görevler yeniden düzenlenmiştir. 73 sayılı Cumhurbaşkanlığı Kararnamesi ile daha önceden kamu personel sisteminin merkezi yönetimine yönelik Aile, Çalışma ve Sosyal Hizmetler Bakanlığı Çalışma Genel Müdürlüğünde olan görev ve

\footnotetext{
16 “Devlet Personel Dairesi Kurulması hakkında Kanun”, RG:17.12.1960, Sayı:10683

${ }^{17}$ 08.06.1984 tarihli Bakanlar Kurulu kararına istinaden 217 sayılı KHK, RG:18.06.1984, Sayı:18435 mükerrer

${ }^{18}$ Devlet Personel Başkanlığının kuruluşu, faaliyetleri ve kapatılması ile ilgili değerlendirmeler kapsamında bkz. (Güler, 1988; Oral, 2019; Albayrak, 2020b)
} 
sorumlulukların büyük bir bölümü Cumhurbaşkanlığı İdari İşler Başkanlığı Personel ve Prensipler Genel Müdürlüğüne verilmiştir.

Cumhurbaşkanlığı Hükümet Sistemine geçiş sonrası kamu personel sisteminin en çok ön plana çıkan özelliği “dağınık” olmasıdır. Oysa etkinlik ve verimlilik sağlanması için kamu personel sisteminin tek elden yönetilmesi bir zorunluluktur. Kamu personel sistemindeki aksaklıklar doğal olarak liyakat ilkesinin uygulamadaki etkinliğini de olumsuz olarak etkilemektedir. Liyakat sisteminin geliştirilmesi için öncelikle kamu personel sisteminin dağınık yapısının düzeltilmesi ve kamu personel sistemine yönelik merkezi faaliyetleri tek elden yürütecek ve eşgüdümünü sağlayacak merkezi bir personel örgütünün tesis edilmesi ihtiyacı ön plana çıkmaktadır. Söz konusu kurumun siyaseten tarafsız kararlar alabilmesi de liyakat ilkesi kapsamında önem arz etmektedir. Nitekim liyakat sistemi, beraberinde sistemin uygulama ve denetlenmesi için merkezi bir teşkilatın olması fikrini de beraberinde getirmiş; sistemin başarıyla uygulandığı ülkelerde siyasi çevrelerin keyfi müdahalelerinden korunan tarafsız ve özel kurumların teşkil edilmesine yönelik özel kanuni tedbirler alınmıştır (Adal, 1968, s. 104).

73 sayılı Cumhurbaşkanlığı Kararnamesi ile yapılan düzenlemeyle Aile, Çalışma ve Sosyal Hizmetler Bakanlığı Çalışma Genel Müdürlüğünün kamu personel sistemi ile ilgili yetki ve sorumluluklarının Cumhurbaşkanlığı İdari İşler Başkanlığı Personel ve Prensipler Genel Müdürlüğüne verilmesini olumlu bir düzenleme olarak nitelemek mümkündür. Ancak yapılan bu düzenlemeyle Devlet Personel Başkanlığının yerini söz konusu Genel Müdürlüğün aldığını söylemek doğru olmayacaktır. Başta Cumhurbaşkanlığı Strateji ve Bütçe Başkanlığı olmak üzere diğer kamu kurumlarının kamu personel sisteminin merkezi yönetimine yönelik bazı sorumlulukları devam etmektedir. Örneğin "Kamu personeli ile ilgili hususlarda her çeşit istatistiki bilgileri toplamak, personel kayıtlarını merkezi olarak tutmak, kurumlar arası veri paylaşımı ve değişimi için gerekli teknik koordinasyonu sağlamak." Cumhurbaşkanlığı Strateji ve Bütçe Başkanlığı Bütçe Genel Müdürlüğünün görevidir. "Kamuda kariyer yönetimi, performans yönetimi ve diğer modern insan kaynă̆ı yönetim modellemelerinin hayata geçirilmesi için projeler gelişstirmek." ve "Kamu istihdamında liyakat ve yetkinliğin artırllması için gerekli projeleri üretmek ve çalışmalar yapmak." Cumhurbaşkanlığı İnsan Kaynakları Ofisinin görevleri arasındadır. "İstihdam fazlası personelin diğer kamu kurum ve kuruluşlarına nakil işlemlerini yürütmek" ve "Kamu görevlileri sendikalarına ilişkin mevzuatın uygulanmasında personel konularında uygulama birliğini sağlayacak tedbirleri almak" görevleri Çalışma ve Sosyal Güvenlik Bakanlığı Çalışma Genel Müdürlüğündedir. 
Cumhurbaşkanlığı Kararnamelerinde Devlet Personel Başkanlığı ifadesinin geçtiği maddeler değiştirilmiş olmakla beraber bu makalenin hazırlandığı tarih itibariyle 657 sayılı DMK'de Devlet Personel Başkanlığına verilmiş olan birçok görevle ilgili de değişiklik yapılmamıştır.

Türk kamu personel sistemine yönelik eleştirilerden birisi Anayasa'nın 128'inci maddesinde "Memurların ve diğer kamu görevlilerinin nitelikleri, atanmaları, görev ve yetkileri, hakları ve yükümlülükleri, aylık ve ödenekleri ve diğer özlük işleri kanunla düzenlenir." hükmü yer almasına rağmen kamu personeline yönelik birçok düzenlemenin KHK'lerle yapılmış olmasıdır. Cumhurbaşkanlığı Hükümet Sistemine geçiş ile birlikte KHK'lerin yerini Cumhurbaşkanlığı Kararnameleri almıştır. KHK ile Cumhurbaşkanlığı Kararnameleri arasındaki temel fark KHK yayımlama yetkisinin Meclis tarafından çıkarılan yetki kanunu kapsamında hükümete belli konularda ve süreli olarak verilen bir yetki iken, Cumhurbaşkanlığı Kararnamesinin Cumhurbaşkanına Anayasa'yla verilen sürekli bir yetki olmasıdır. ${ }^{19}$

2017 yılında yapılan anayasa değişikliği ile Cumhurbaşkanına temel haklar, kişi hakları ve ödevleri, siyasi haklar ve ödevler dışında olmak şartıyla yürütme yetkisine ilişkin konuları Cumhurbaşkanlığı Kararnamesiyle düzenleme hakkı verilmiştir (Anayasa madde 104). Ancak Cumhurbaşkanlığı Kararnameleri incelendiğinde kamu personelinin statüsü ile mali ve sosyal haklarının da kararnamelerle düzenlendiği görülmektedir. Örneğin Sigortacılık ve Özel Emeklilik Düzenleme ve Denetleme Kurumu 47 sayılı Cumhurbaşkanlığı Kararnamesi ile kurulmuş, Kurumdaki kamu personelinin statüsü ile mali ve sosyal hakları Kararname ile belirlenmiştir. Benzer şekilde 12 sayılı Cumhurbaşkanlığı Kararnamesi ile Millî Saraylar İdaresi Başkanlığının kuruluş, görev yetkileri ile birlikte Kurumda görev yapacak kamu personelinin istihdamı, çalıştırılması ve özlük haklarına yönelik esaslar da belirlenmiştir. Bu durumda, Anayasa'nın 104'üncü maddesiyle Cumhurbaşkanına verilen yetki kapsamında çıkarılan Cumhurbaşkanlığı Kararnamelerinin Anayasa'nın 128'inci maddesine uygunluğu tartışmalıdır. Anayasa Mahkemesi tarafindan verilen kararlar da bu tespiti destekleyecek niteliktedir. Örneğin Anayasa Mahkemesinin 24 Temmuz 2019 tarihli ve 2019/65 sayıl1 kararında sözleşmeli sağlık personeli Anayasa'nın 128'inci maddesinde belirtilen diğer kamu görevlileri statüsünde değerlendirilmiş; bu personelin nitelikleri, atanmaları, görev ve yetkileri, hakları ve yükümlülükleri, aylık ve ödenekleri ile diğer özlük işlerine yönelik temel ilkelerin kanunla belirlenmesi gerektiği belirtilmiştir. Bu kapsamda kamu personelinin statüsünü ve

\footnotetext{
${ }^{19}$ Cumhurbaşkanlığı Kararnamesiyle KHK'lerin karşılaştırılması için bkz. (Keskinsoy, Kaya ve Meri: 2020)
} 
özlük haklarını belirleyen düzenlemelerin TBMM tarafından çıkarılacak kanunlarla yapılması daha uygun olacaktır.

\section{Sonuç Yerine}

Türk kamu personel sisteminin liyakatle ilgili problem sahalarının yasal mevzuat, resmi raporlar, yargı kararları ve Sayıştay denetim raporları gibi somut veri kaynakları üzerinden değerlendirildiği bu çalışmada elde edilen bulgular genel itibariyle alanyazında yer alan değerlendirmelere paraleldir. Bununla beraber çalışmada alanyazında yer almayan hususlara da değinilmiş ve bazı konularda somut önerilerde bulunulmuştur. Diğer yandan bulguların mevzuatta yapılan değişiklikler, yargı kararları, Sayıştay denetleme raporları gibi nesnel verilere dayanması çalışmayı benzerlerinden ayıran bir husus olmuştur.

Mevcut durumda kamu personel sisteminin öne çıkan özelliği "dă̆ınık” bir yapıda olması ve bütüncül olarak belirlenmiş esaslar doğrultusunda işletilmemesidir. Bu durum liyakat ilkesinin uygulanmasını da olumsuz olarak etkilemektedir. Kamu personel sisteminde liyakat ilkesinin uygulanmasına olumsuz etki eden hususlardan bir diğeri ise genel esaslardan uzaklaşarak istisnalar yaratılmasıdır. Örneğin DMK'de sözleşmeli personel istihdamı ile ilgili hususlar yer almakta iken hem söz konusu maddenin devamına istisnalar siralanması, hem de değişik kanunlarla DMK'de belirtilenden farklı sözleşmelilik statüleri oluşsturulması sözleşmeli istihdamla ilgili düzenlemelerin bütünlügünü bozmaktadır. Kamu Görevlerine İlk Defa Atanacaklar İçin Yapılacak Sınavlar Hakkında Genel Yönetmelik’te (B) grubu kadrolara yerleştirmelerin merkezi olarak yapılması öngörülmüşken, mahallî idarelerin ve bazı diğer kadroların bu düzenlemeden çıkarılması istisnalar yoluyla genel esaslardan uzaklaşılmasına verilebilecek diğer bir örnektir. Yapılan bu tür uygulamalar kamu personel rejimini sistemsiz hâle getirmektedir. $\mathrm{Bu}$ durumda kamu personel sistemine sahip çıkacak ve yapılacak düzenlemelerin genel esaslara uygun olmasını gözetecek merkezi bir kurum ihtiyacı gündeme gelmektedir. 1960 yılında kurulan Devlet Personel Dairesi/Başkanlığı değişik nedenlerden dolayı (Albayrak, 2020b, ss. 1520-1528; Oral, 2019, ss. 408-411) bu görevi tam olarak yerine getirememiştir. Cumhurbaşkanlığ 1 Hükümet Sistemine geçişle birlikte Devlet Personel Başkanlığı kapatılmış, kamu personel sistemine yönelik yetki ve sorumluluklar değişik kurumlar arasında paylaştırılmıştır.

Merkezi personel örgütünün gerekliliği konu ile ilgili çalışmalar yapan birçok akademisyen tarafından da dile getirilmiş olup bu çalışmada da farklı bir bakış açısıyla aynı sonuca ulaşılmıştır. 2018 yılı Temmuz ayında yayımlanan 703 sayılı KHK ile Devlet Personel Başkanlığının bir yıl sonra kapanmış sayılacağı belirtilmiş olmasına rağmen DMK ve diğer 
yasal mevzuatta Kuruma verilen görevlerin birçoğunda değişiklik yapılmamış, hatta daha sonra çıkartılan Cumhurbaşkanlığı Kararnamelerinde Kuruma çeşitli görev ve sorumluluklar verilmiştir.

Oral'a göre (2019, s. 415) Devlet Personel Başkanlığının kapatılmasının bir yıl sonraya bırakılması ve Kuruma görev verilmeye devam edilmesi siyasi iradenin Kurumun kapatılmasına yönelik kararının net olmadığını göstermektedir. Siyasi iradeyi bu kafa karışıklığına sürükleyen nedenin etkin bir kamu personel sisteminin tesis edilebilmesi için merkezi bir kuruma olan ihtiyacın çok açık olması olduğu söylenebilir. Nitekim 2021 yılı Mart ayında açıklanan Ekonomi Reformları Eylem Planı'nda kamu personeline dair iş ve işlemlerin tek bir idare tarafından yürütülmesinin sağlanacağı (Eylem No: 1.1.j.) ifade edilmiş; Nisan 2021 ayında 73 sayılı Cumhurbaşkanlığı Kararnamesi ile yapılan değişiklikle Aile, Çalışma ve Sosyal Hizmetler Bakanlığı Çalışma Genel Müdürlüğünün kamu personel sistemi ile ilgili yetki ve sorumlulukları Cumhurbaşkanlığı İdari İşler Başkanlığı Personel ve Prensipler Genel Müdürlüğüne aktarılmıştır. Ancak başta Cumhurbaşkanlığı Strateji ve Bütçe Başkanlığı olmak üzere bazı kamu kurumlarının kamu personel sisteminin merkezi yönetimine yönelik yetki ve sorumlulukları devam etmektedir. Nisan ayında yapılan değişiklik sonrası kamu personel sistemine yönelik merkezi örgütlenme yapısının ve Cumhurbaşkanlığı İdari İşler Başkanlığı Personel ve Prensipler Genel Müdürlüğünün teşkilat, kadro, insangücü ve yetki açısından yeterliliğinin ayrı bir çalışmada incelenmesi gerekir.

Liyakat ilkesine yönelik önerilerden birisi de ABD Liyakat Sistemini Koruma Kuruluna benzer bir kurumun kurulmasıdır. Bu kapsamda Öztürk (2002) tarafından bağımsız idari otorite statüsünde, merkezde ve taşrada il seviyesinde örgütlenecek "Liyakat İlkesi Koruma Kurulu" adı altında bir kurulun oluşturulması önerilmiştir. Değişik akademisyenler tarafından da farklı teşkilata ve görevlere sahip liyakatle ilgili teşkilatlanma önerileri yapılmıştır. ${ }^{20} 1982$ Anayasası'nın hazırlanması esnasında liyakat ilkesine yönelik teşkilat kurulmasına yönelik önerge verilmiş ancak kabul edilmemiştir. ${ }^{21} 2021$ yılında, Milliyetçi Hareket Partisi tarafından hazırlanan anayasa taslağında “Türkiye Liyakat Kurumu”nun kurulması önerilmiştir.

Kamuda liyakat ilkesinin geliştirilmesine yönelik politikalar üretmek, uygulanan politikaları değerlendirilmek ve liyakat ilkesinin ihlaline yönelik şikâyetleri incelemekle

\footnotetext{
20 "Merkezi Personel Hizmetleri Örgütlenmesi Araştırma Projesi (PERHIZ) Raporu", Aslan vd. 2016, s. 200, 205, 225; Oral, 2019, ss. 430-431

${ }^{21} 1982$ Anayasası'nın hazırlanması esnasında Anayasa Komisyonunda görevli Cahit Tutum tarafından "Devlet, liyakat sisteminin eşit imkânlarda uygulanmasını gözetmek için gerekli tedbirleri alır ve teşkilatı kurar" ifadesinin Anayasa'da yer alması için önerge verilmiş, ancak kabul edilmemiştir (Günay, 2007, ss. 66-74).
} 
görevli merkezi bir kurum teşkil edilmesi liyakate dayalı bir kamu personel sisteminin geliştirilmesine katkı sağlayacaktır. Bu konuda farklı bir alternatif ise kamu personelinin bütününden sorumlu olacak güçlü bir merkezi kuruma liyakat ilkesinin geliştirilmesine yönelik de yetki ve sorumluluk verilmesidir. Ayrı bir kurum teşkil edilmesi durumunda bu kurumun politikaların belirlenmesi, değerlendirilmesi, raporlanması ve şikâyetlerin incelenmesinden sorumlu olması, mevzuat düzenlemelerinin merkezi personel örgütü tarafından yerine getirilmesi uygun olacaktır. Liyakatle ilgili kurulacak kurumun siyaseten tarafsızlığına ve kısmi bağımsızlığına özellikle önem verilmesi, bu kapsamda TBMM'ye bağlı olarak anayasal bir örgüt olarak teşkil edilecek kurumun Kamu Denetçiliği Kurumuna benzer bir şekilde örgütlenmesi ve kurumun başkanının TBMM tarafından seçilmesi uygun olacaktır. Liyakatle ilgili konularda yapılacak çalışmaları değerlendirmek üzere kurum içinde ayrıca bir kurul teşkil edilmesi durumunda bu kurulda siyasi parti temsilcilerinin yanında, Danıştay ve Sayıştay temsilcileri ile belirli sayıda akademisyenin de görev alması değerlendirilebilir.

Çalışmada öne çıkan diğer bir husus kamu personel sistemine yönelik esasların bütüncül olarak tekrar değerlendirilmesi ve yeni bir kamu personel kanunu hazırlanmasına yönelik ihtiyaçtır. Her ne kadar DMK'de kamu personel sisteminin temel ilkeleri "sinıflandırma", "kariyer" ve "liyakat" olarak ifade edilmiş olsa da başta kariyer olmak üzere bu ilkelerin ne ölçüde uygulandığı oldukça tartışmalıdır. Bunun yanında bu üç ilke ve mevcut yasal düzenlemeler liyakate dayalı bir kamu personel sisteminin tam olarak uygulanabilmesi için yeterli olamayabilmekte olup bazı alanlarda yeni esaslar belirlenmesi gerekmektedir. Kamu personel sistemine yönelik genel esasların belirlenmesini müteakip Anayasa'nın kamu görevlileri ile ilgili maddelerinin yeniden düzenlenmesi ve tüm kamu personelinin tabi olduğu genel esasları içeren DMK'nin yerine geçecek temel bir personel kanunu hazırlanması uygun olacaktır. Bu konuda icra edilecek çalışmalara ilgili kamu görevlileri ve akademisyenlerin yanında Sayıştay ve Danıştay temsilcilerinin de katkı sağlaması fayda sağlayacaktır. Çalışmaların Meclis çatısı altında yapılması hâlinde tüm siyasi partiler de çalışmalara dâhil olabilecektir.

Yeni bir kamu personel kanunu hazırlanması ihtiyacı resmi dokümanlarda da ifade edilmiş, birçok akademisyen tarafından da dile getirilmiştir. Bu çalışmada farklı olarak; siyasetin ve üçüncü kişilerin olumsuz etkisine karşı alınacak tedbirler, kamu personeline sağlanacak güvenceler, ücretlerde birlik ve denkliğin sağlanması, etkin bir değerlendirme sistemi tesis edilmesi, yetersiz personelin görevine son verilmesi, kamu personelinin eğitiminin 
geliştirilmesi gibi liyakat sistemine yönelik alt unsurların da belirlenip kamu personel kanununa eklenmesi önerilmektedir.

Merkezi sınavların kişinin göreve uygunluğunu tam olarak tespit edebilmek için yetersiz kalması, özellikle bazı görevler için ayrıca sözlü ve/veya uygulamalı sınav yapılmasını gerekli kılmaktadır. Ancak liyakatle ilgili en çok eleştirilen konulardan birisi de sözlü sınav ve mülakatların kayırmacılık aracı olarak kullanılıyor olmasıdır. Çalışmada bu probleme yönelik olarak, şeffaflık ve tarafsızlıkla ilgili gerekli tedbirlerin alınması şartıyla sözlü sınavların konunun uzmanı personel tarafından merkezi olarak yapılması konusunun incelenmesi önerilmiştir.

2018 yılında 703 sayıl1 KHK ile kapat1lan kurumlardan biri de TODAİE'dir. Her ne kadar TODAİE’nin görevini tam olarak yerine getiremediği yönünde eleştiriler yapılmış olsa da kamu personelinin eğitilmesine yönelik önemli bir görevi yerine getiren söz konusu kurumun kapatılmış olması liyakat sistemine yönelik önemli bir eksiklik ortaya çıkarmıştır. Bu kapsamda geçmişte TODAİE tarafından yerine getirilen, kamu yönetimi alanında akademik çalışmalar yapmak ve kamu personelinin eğitimi ile ilgili konuları merkezi olarak yürütmekten sorumlu olacak yeni bir kurumun tesis edilmesi uygun olacaktır. Fransız yönetim okulu ENA örneğinde olduğu gibi, yeni teşkil edilecek bu kuruma üst kademe kamu yöneticilerinin yetiştirilmesinin yanında seçilmesine yönelik de yetki ve sorumluluk verilmesi liyakat sistemine katk1 sağlayacaktır. Diğer yandan kamu personelinin hizmet içi eğitiminin geliştirilmesine yönelik mevzuatın yeniden gözden geçirilmesi ihtiyacı çalışmada tespit edilen diğer bir husustur.

2011 yılında kaldırılan sicil sisteminin yerine geçecek yeni bir değerlendirme sisteminin tesis edilememiş olması, merkezi sınav sonuçlarına göre hizmete alınan kamu personeli sayısının azalması, yasal mevzuata uygun olmayan vekâleten atamaların yaygın olarak yapılması, kamu personelinin statüsünün değiştirilmesine yönelik düzenlemelerin liyakat sistemine olumsuz etkisi ve kamu personeline yönelik düzenlemelerin kanunla yapılmasının gerekliliği çalışmada belirlenen diğer tespitler olmuştur.

Türk kamu personel sisteminin liyakatle ilgili problem sahaları kapsamında kamuda istihdam şekilleri, üst kademe kamu yöneticileri, istisnai memurluk ve kariyer mesleklerle ilgili hususlar ile görevde ilerleme ve yükselmeler, görevin sona erdirilmesi aşamalarına yönelik konular ayrı bir makalede değerlendirilecektir. 


\section{KAYNAKÇA}

Adal, H. Ş. (1968). Kamu personel idaresi. İstanbul:Ahmet Sait Matbaas1.

Akgüner, T.(2014). Kamu personel yönetimi. 6'ncı Baskı. İstanbul:DER Yayınları.

Albayrak, S. O. (2020a). Türkiye'de üst kademe kamu yöneticiliğine atanma. Memleket Siyaset Yönetim Dergisi, 15(33), 101-140.

Albayrak, S. O. (2020b). Türkiye'de kamu personel yönetiminin yeni kurumsal yapısı ve kamu istihdamının yeni görünümü. Ankara Üniversitesi Siyasal Bilgiler Fakültesi Dergisi, 75(4), 1517-1549.

Aslan, O. E. vd. (2016). Merkezi personel hizmetleri örgütlenmesi. 1'inci Basım. TODAİE Yayın No:396. Ankara. 91-109.

Aykaç, B. (1990). Personel yönetiminde yeterlik ilkesi. Amme İdaresi Dergisi, 23(4),

Canman, D. (1995). Çăgdaş Personel Yönetimi. TODAİE Yayınları. No: 260. Ankara.

Creswell, J. W. (2013). Nitel araştırma yöntemleri, beş yaklaşıma göre nitel araştırma ve araştırma deseni. 3'üncü Baskı. Çeviri Editörleri: Mesut BÜTÜN, Selçuk Beşir DEMİR, Ankara:Siyasal Kitabevi.

Dreyfus, F. (2007). Bürokrasinin Ícadl: Fransa, Büyük Britanya ve ABD'de devlete hizmet etmek (18.-20. yüzyıl). Çeviren: Işık Ergüden. 1'inci Baskı. İstanbul:İletişim Yayınları.

Devlet Personel Dairesi. (1962). Devlet personel rejimi hakkında ön rapor. Ankara.

Devlet Personel Dairesi. (1963). Hükümete sunulan yabancı uzman raporları (19491959 yılları arasında). Ankara.

Devlet Personel Dairesi. (1963). 1962 Yllinda Devlet Personel Dairesi'ne verilen yabancı uzman raporları. Ankara.

Devlet Planlama Teşkilatı. (2000). Sekizinci Beş Yıllık Kalkınma Planı, Kamu Yönetiminin İyileştirilmesi ve Yeniden Yapılandırılması Özel İhtisas Komisyonu Raporu. DPT: 2507 - ÖİK: 527. Ankara.

Devlet Planlama Teşkilatı. (2001). Sekizinci Beş Yıllık Kalkınma Planı, Yerel Yönetimler Özel İhtisas Komisyonu Raporu. DPT: 2538- ÖİK: 554. Ankara.

Eryılmaz, B. (2016). Kamu yönetimi, düşünceler, yapılar, fonksiyonlar, politikalar. 9'uncu Bask1. İstanbul:Umuttepe Yayınları.

Gönülaçar, Ş. (2014). İnsan kaynakları yönetiminde kayırmacılık kuşatması ve liyakatsizlik çıkmazı, https://www.academia.edu/9687458 (Erişim:28.03.2021).

Güler, B. A. (1988). Devlet personel başkanlığı üzerine bir inceleme (1). Amme İdaresi Dergisi, 21(1), 79-99. Kitabevi.

Güler, B. A. (2013). Kamu personeli, sistem ve yönetim. 2'nci Bask1. Ankara:İmge

Güran, S.(1980). Memur hukukunda kayırma ve liyakat sistemleri. İstanbul:İstanbul Üniversitesi Fakülteler Matbaası.

Günay, Ö. F. (2004). Üst düzey kamu yöneticilerinin yetiştirilmesi. Yayımlanmamış Doktora Tezi. Ankara Üniversitesi, Ankara.

Günay, Ö. F.(2007). Türkiye'de kamu yöneticisi yetiştirmenin gerekliliği ve anayasamızdaki yeri. Amme İdaresi Dergisi, 40(2), 57-78.

Heper, M. (1977). Türk Kamu Bürokrasisinde Gelenekçilik ve Modernleşme. İstanbul: Boğaziçi Üniversitesi Yayını.

Keskinsoy, Ö.,Kaya, S. B. ve MERİ, T.(2020). Cumhurbaşkanlığı kararnamesi. Ankara Üniversitesi Siyasal Bilgiler Fakültesi Dergisi, 75(4), 1383-1416.

Meriç, O. (1974). Siyasal iktidar ve yüksek yöneticiler sorunu. Amme İdaresi Dergisi, 7(3), 73-78. 
Oral, İ. (2019). Merkezi personel yönetimi örgütlenmesi: ABD ve Japonya örnekleri ve Türkiye için bir model önerisi. Yayımlanmamış Doktora Tezi. Hacettepe Üniversitesi, Ankara.

Öztürk, N.K. (2002 Haziran). Liyakat sistemini korumanın farklı bir yolu: liyakat ilkesi koruma kurulu, Türk Idare Dergisi, Sayı 435, 129-143.

Sayan, İ.Ö. ve Demirci, A. G. (2018). Kamu personelinin değerlendirilmesinde performans sistemine geçiş sürecinin analizi. Ankara Üniversitesi SBF Dergisi, 73(2), 667-700.

Saydam, M. (2018). Türk kamu yönetimi için önerilen yeni değerlendirme sistemi: personel başarı değerlendirme sistemi (PBDS). Yasama Dergisi, Sayı 38, 70-109.

Sezer, Y. (2003). Kamu Hizmetine Girme Hakkı ve Liyakat İlkesi Açısından İstisnai Memurluklar. Selçuk Üniversitesi Hukuk Fakültesi Dergisi, 11(3-4), 173-193.

Şen, M. L. (1995). Liyakat ilkesi ve Türk personel sistemindeki uygulamas1. Amme Idaresi Dergisi, 28(1), 77-92.

T.C. Kalkınma Bakanlığı. (2018). On Birinci Kalkınma Planı, Kamuda İnsan Kaynakları Çalışma Grubu Raporu. ÖİK: 825. Ankara.

T.C. Strateji ve Bütçe Başkanlığı.Kalkınma Planları (1-11'inci Kalkınma Planları), http://www.sbb.gov.tr/kalkinma-planlari/

TODAİE. (1966). Merkezî hükümet teşkilâtı araştırma projesi yönetim kurulu raporu. 2'nci Baskı. Ankara.

TODAİE.(1972). İdari reform danışma kurulu raporu: idarenin yeniden düzenlenmesi ilkeler ve öneriler. TODAİE Yayınları No:123. Ankara:Sevinç Matbaası.

TODAİE. (1991). Kamu yönetimi araştırması genel rapor. TODAİE Yayınları No:238. Ankara:Devlet İstatistik Enstitüsü Matbaas1.

Turan, A. (2018). Türkiye'nin yeni yönetim düzeni: Cumhurbaşkanlığı hükümet sistemi. Social Sciences Research Journal, 7(3), 42-91.

Tutum, C. (1979). Personel Yönetimi. Ankara:TODAİE.

Yıldız, G. (2019). Devlet Memurları Kanunu: Türk kamu personel rejimi için bitmeyen tartışma. Ufuk Üniversitesi Sosyal Bilimler Enstitüsü Dergisi, Sayı:15, 413-437.

Yılmaz, F. (2020). Kamu Çalışanları Bakış Açısından Liyakat Ihlali Algısı, Kaynakları ve Yansımaları. Yayınlanmamış Doktora Tezi. Mersin Üniversitesi, Mersin.

Yin, R. K. (2009). Case Study Research Design and Methods. 4th Edition.California: Sage Publications. 